\title{
Germany: Submerged Sites in the South-Western Baltic Sea and the Wadden Sea
}

\author{
Hauke Jöns, Friedrich Lüth, Svea Mahlstedt, \\ Julia Goldhammer, Sönke Hartz, \\ and Hans-Joachim Kühn
}

\begin{abstract}
Only in the last 20 years have German research institutes and heritage agencies turned their attention to the investigation of the settlements that were inundated by rapid sea-level rise during the Holocene. Over 142 sites have been recorded so far, the majority on the Baltic coastline, and mostly of Late Mesolithic and Early Neolithic date. Underwater excavations on the Baltic coast of sites such as TimmendorfNordmole, Neustadt and Strande demonstrate
\end{abstract}

H. Jöns $(\bowtie)$

Lower Saxony Institute for Historical Coastal

Research, Wilhelmshaven, Germany

e-mail: joens@nihk.de

F. Lüth

German Archaeological Institute, Berlin, Germany

e-mail: Friedrich.Lueth@dainst.de

\section{S. Mahlstedt}

Lower Saxony Institute for Historical Coastal

Research, Wilhelmshaven, Germany

e-mail: mahlstedt@nihk.de

\section{J. Goldhammer}

State office for Cultural Heritage Baden-

Wuerttemberg, Gaienhofen-Hemmenhofen, Germany

e-mail: Julia.goldhammer@rps.bwl.de

\section{S. Hartz}

Museum for Archaeology Schloss Gottorf,

Schleswig, Germany

e-mail: soenke.hartz@landesmuseen.sh

\section{H.-J. Kühn}

State Archaeology Department of Schleswig-

Holstein, Schleswig, Germany the presence of large and well-preserved assemblages of stone, antler and wooden artefacts and other cultural features, comparable to the better-known underwater settlements of Denmark. Research within the framework of the SINCOS project has led not only to the discovery of numerous Stone Age settlements but also to a high-resolution reconstruction of the changes in coastal palaeogeography associated with the Littorina transgression. It has also raised the profile of the submerged Stone Age as a significant feature of the cultural heritage and demonstrated the value of and the need for multi-disciplinary collaboration. Fewer finds have been recovered on the North Sea coast, and this reflects the different environmental history of marine transgression, the greater thickness of marine sediments masking the prehistoric land surface and the greater technical challenges required to access it. Most finds here have been disturbed, a notable exception being the Late Neolithic votive deposit of an aurochs at Hamburger Hallig. The situation is also influenced by the legal and structural requirements imposed on research and the protection of sites by the relevant authorities in the various federal states: Mecklenburg-West Pomerania (Baltic Sea), Schleswig-Holstein (North Sea and Baltic Sea) and Lower Saxony (North Sea). 


\section{Keywords}

Littorina transgression - Mesolithic ·

Neolithic $\cdot$ SINCOS project $\cdot$ Submerged landscapes $\cdot$ Submerged sites $\cdot$ Underwater archaeology

\subsection{Introduction}

Germany, like neighbouring Denmark, has both a Baltic and a North Sea coastline, each with very different records of marine transgression and submerged archaeology. Systematic underwater archaeological investigations have focussed mainly on the Baltic coast, and though they began later than in Denmark, they have produced information of equivalent interest and importance, mostly of Late Mesolithic or Early Neolithic date. Currently there are 142 sites in the SPLASHCOS Viewer, the majority (100) from the Baltic coast (http://splashcos-viewer.eu/) (Fig. 5.1). Almost all these sites are shallow-water finds $(<10 \mathrm{~m})$. Some were chance discoveries by divers, many were discovered by systematic research-led investigations. Collaboration with offshore development projects has taken place in recent years through Environmental Impact Assessments conducted in advance of industrial development. Notable examples are the construction of a tunnel between Lolland in Denmark and Fehmarn in Germany, and the Nord Stream gas pipeline, which passes along the Baltic seabed from NW Russia to NE Germany. Both projects have involved geophysical and geological investigations of submerged landscapes but so far without significant discoveries of archaeological material except on the Danish side of the Fehmarnbelt tunnel (Enters et al. 2015; Sørensen 2016).

The beginnings of underwater investigations of submerged Stone Age sites in Germany go back to the nineteenth century, when occasional

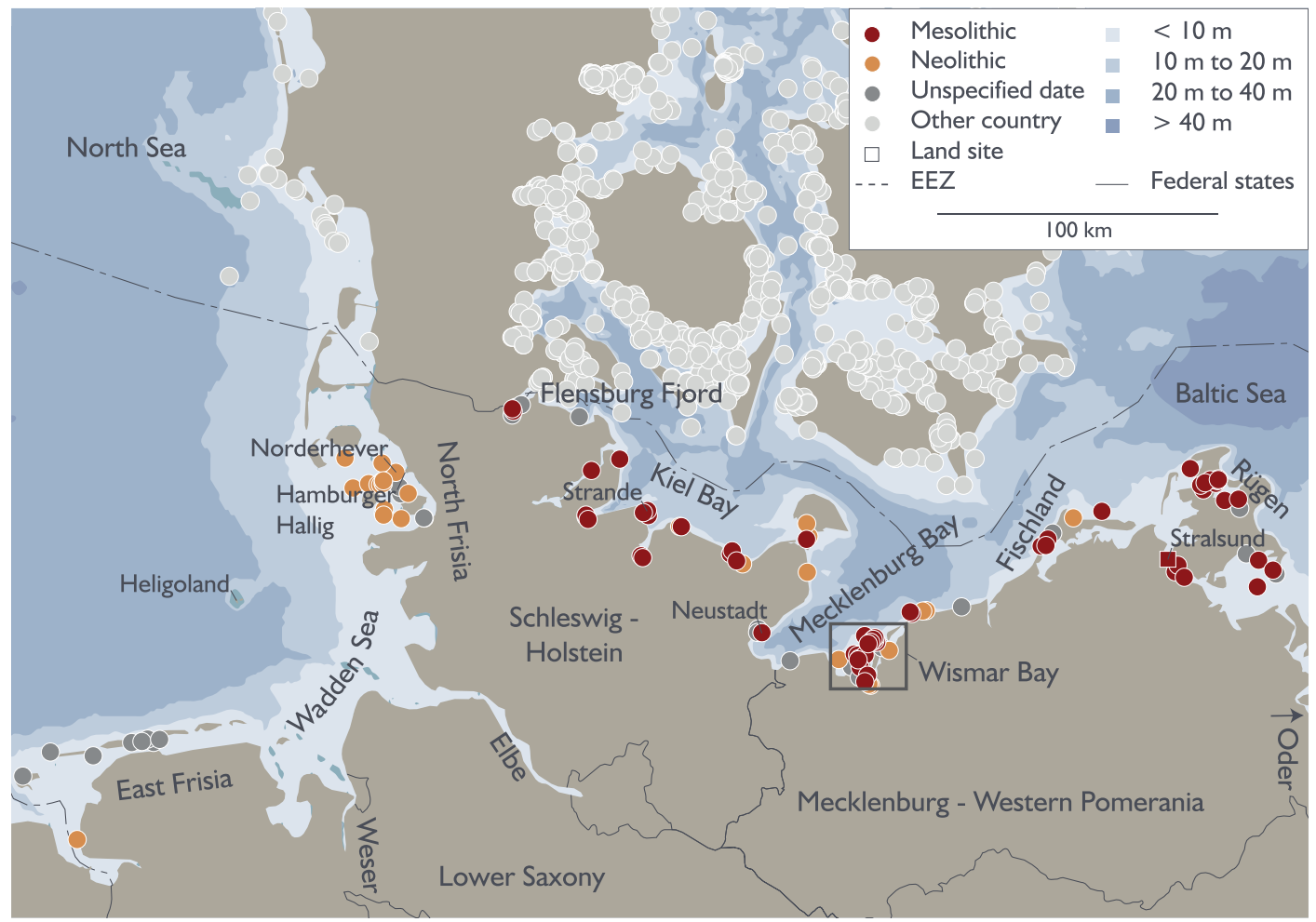

Fig. 5.1 Map of Germany showing distribution of underwater sites, key names and other places mentioned in the text. Site information from the SPLASHCOS Viewer http://splashcos-viewer.eu/. Drawing by Moritz Mennenga 
Mesolithic finds brought up by offshore dredging were first recognised, and to closer collaboration of geologists and archaeologists in the midtwentieth century, who began to unravel the history of Postglacial sea-level rise in the Baltic and its relationship to the Mesolithic-Neolithic transition (Jöns et al. 2007). However, systematic underwater research did not begin until the 1990s, inspired by the publication of the impressive results of work going back to the 1970s in neighbouring Denmark (e.g. Skaarup 1995) and by the culmination of research on the pile dwellings of Lake Constance in southern Germany (Schlichtherle 1997). The earliest investigations of submerged sites took place at the western end of the Mecklenburg Bight on the Baltic coastline of Schleswig-Holstein (Harck 1985).

An important boost to underwater research followed German reunification in 1990. Before then, the Baltic coastline of Mecklenburg-West Pomerania had been part of East Germany (the German Democratic Republic) since 1949 and civilian underwater research was prohibited. After 1990, investigations began to reveal underwater Mesolithic and Neolithic finds. These discoveries involved close cooperation between archaeological museums, heritage authorities and geological research institutes, a collaborative network that culminated in the multi-disciplinary SINCOS (Sinking Coast) project funded by the German Research Foundation (DFG) from 2002 to 2010 (Harff and Lüth 2007, 2011). This project with its collaboration between specialists in geology, archaeology, palaeobotany, archaeozoology, dendrochronology and palaeoclimatology resulted in systematic investigation of submerged shorelines and archaeology over wide areas of the Mecklenburgian and Pomeranian Bights and the discovery of some 50 new underwater archaeological sites (see Jöns 2011; Hartz et al. 2011). This must count as one of the largest concentrations of underwater prehistoric sites in Europe discovered as a result of research-led systematic exploration. These discoveries, along with excavations at some of the newly discovered sites, have produced evidence that is comparable, in terms of quantity and quality of preservation, to the famous under- water Mesolithic sites of Denmark (see Bailey et al., Chap. 3, this volume).

On the North Sea coastline, underwater sites are fewer and mainly comprise isolated finds recovered by chance following exposure of buried material by storms. This difference is largely due to the very different history of marine inundation and sediment accumulation as compared to the Baltic Sea and different conditions for the exposure and discovery of underwater material (Jöns 2010).

In this chapter we summarise the changing coastal geography and environment associated with sea-level rise since the Last Glacial Maximum (LGM), outline the archaeological context of the underwater finds, synthesise the archaeological results of underwater research with reference to key excavations, examine the variable conditions of underwater archaeological preservation and outline the prospects and challenges for future discoveries.

\subsection{Palaeogeography and Sea- Level Change}

The German coastline today is c. $3500 \mathrm{~km}$, with c. $1500 \mathrm{~km}$ of coastline along the Wadden Sea facing the North Sea and c. $2000 \mathrm{~km}$ on the Baltic (Policy Research Corporation 2009). ${ }^{1}$ It is bordered by three states-Lower Saxony on the North Sea coast, Schleswig-Holstein with both a North Sea and a Baltic coastline and MecklenburgWest Pomerania bordering the Baltic-and it receives drainage from four major rivers: the Ems near the Dutch border and the Weser and the Elbe Rivers, all draining into the North Sea, and the Oder River, which forms the frontier with Poland and flows into the Baltic.

Both coastlines have a history of highly dynamic changes associated with Late Pleistocene and Early Holocene climate change and sea-level

\footnotetext{
${ }^{1}$ Most sources give a length of $2389 \mathrm{~km}$, but these figures are notoriously vulnerable to variation because of fractal effects, and we prefer the larger figure here because it is given in a document specifically concerned with the impact of sea-level rise on the modern coastline.
} 
rise, with marked differences between the North Sea and the Baltic at the broad scale, and differences at a regional scale along the Baltic coastline between Mecklenburg Bay in the west and Rügen Island in the east, and along the Wadden Sea between North Frisia and East Frisia (see Fig. 5.1). The nature of these palaeoenvironmental changes and their impact on prehistoric occupation and on the visibility and preservation of archaeological sites are discussed at the broad scale by Rosentau et al. (2017) for the Baltic and by Cohen et al. (2017) for the North Sea. More localised detail is presented for Denmark by Bailey et al. (Chap. 3, this volume), which has a similar palaeoenvironmental and archaeological sequence to the German coast following the LGM, but with some differences in the German case that are discussed further below.

\subsubsection{The Baltic}

The Baltic Sea today is a mainly brackish-water basin with a connection to the North Sea through the straits of Denmark. Periodically during the Last Glacial period, it was a fully enclosed freshwater basin cut off from the North Sea by a combination of ice barriers and isostatically rebounding land (see Jöns and bailey, Chap. 2, Bailey et al., Chap. 3, and Nilsson et al., Chap. 4, this volume). A fully marine connection to the North Sea was only finally established during the Littorina Transgression at about 8000 cal BP (6000 cal BC). Since then, sea level has continued to rise along parts of the Baltic coastline because of ongoing subsidence associated with glacio-isostatic adjustment following the retreat of the Scandinavian ice sheet (Harff et al. 2007, 2017; Groh et al. 2011; Rosentau et al. 2017; see also Glorstad et al., Chap. 6, this volume).

In central and northern Scandinavia, the Earth's crust and the more viscous material of the underlying mantle were pressed downwards by the main mass of the overlying ice sheet. Conversely, the areas of the Earth's crust around the southern periphery of the ice sheet were pushed upwards by the southward flow of material in the mantle to form a 'forebulge'. As the ice sheets retreated and the downward pressure on the crust and mantle was released, the land beneath slowly rebounded, and the forebulge subsided. Because of the time lag in the response of the crust to these changes in loading, these processes of uplift and subsidence continued long after the final retreat of the ice sheet, and in some areas they continue today. Where the land has rebounded, earlier shorelines have been uplifted, in some areas of northern Scandinavia by as much as $200 \mathrm{~m}$ or more, and there has been a relative drop in sea level. In areas of subsidence, the amount of vertical movement is less $(\leq$ $20 \mathrm{~m}$ ), and here there has been a steady rise in relative sea level and progressive inundation of earlier shorelines.

The rate of relative sea-level regression associated with land rebound is highest in central and northern Scandinavia, where the ice sheet was thickest and the Earth's crust most deeply depressed (Fig. 5.2). The rate of uplift becomes progressively less towards the south, and the boundary between uplift and subsidence passes through southern Denmark and along the western section of the Baltic coast with the highest rates of subsidence and relative sea-level rise in Kiel Bay and Mecklenburg Bay. To the east, this boundary moves on shore, with some degree of uplift and relative sea-level regression further east along the Baltic coastline. This has resulted in different sea-level histories between Wismar Bay in the west and Rügen in the east (Fig. 5.3; Lampe et al. 2007).

More detailed mapping and dating of palaeoshorelines in the Wismar Bay were made possible by combined archaeological and geophysical exploration as part of the SINCOS project and show the changing configuration of the coastline at selected time slices during this period and how much land was lost by progressive encroachment of the sea between $6200 \mathrm{cal} \mathrm{BC}$ and AD 800 (Fig. 5.4).

\subsubsection{The North Sea}

Compared to the Baltic, the changing configuration of topography and coastlines in the North Sea basin with sea-level rise after the LGM 


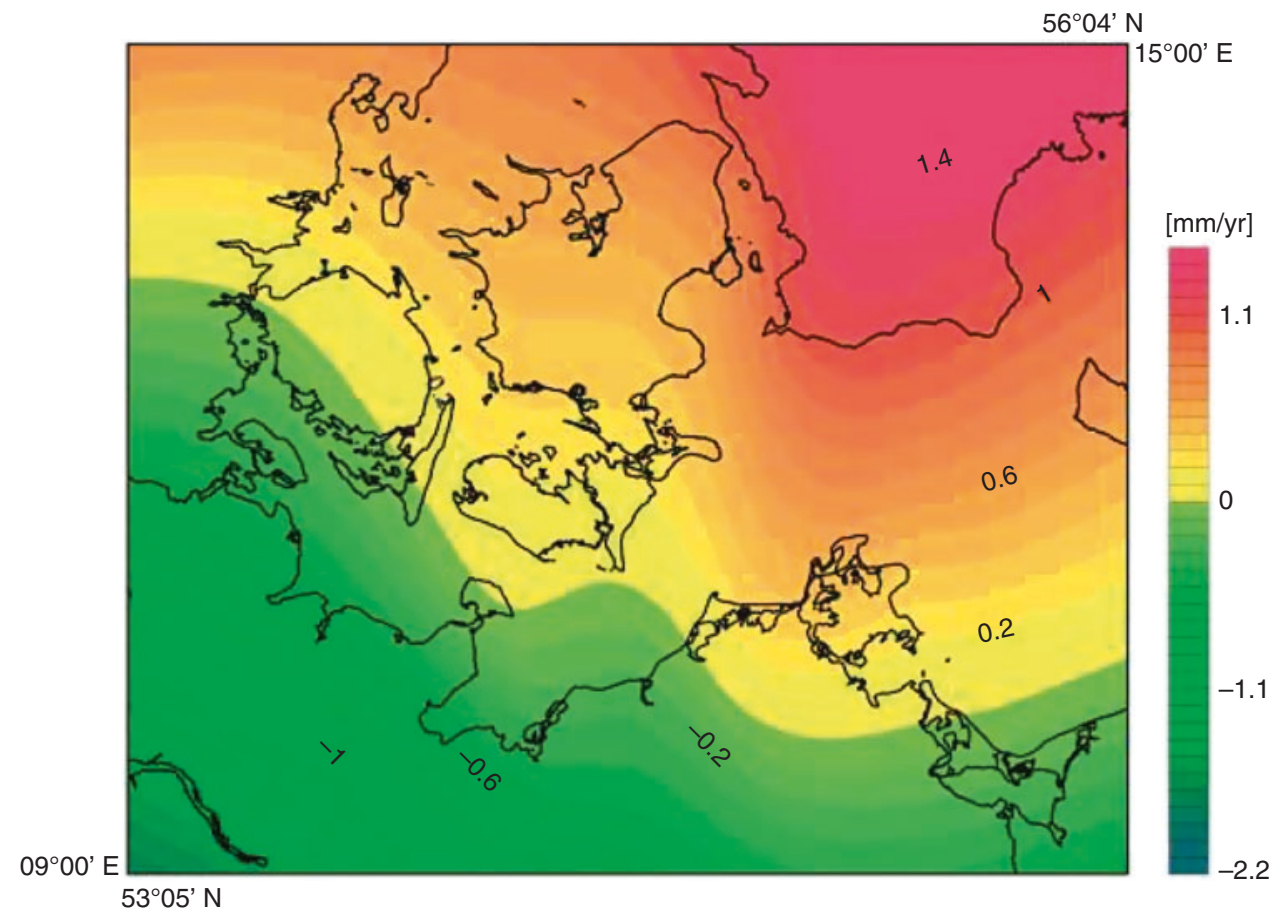

Fig. 5.2 The southwestern Baltic Sea, showing the rate of recent glacio-isostatic adjustment (GIA) based on relative sea-level change data reduced by an eustatic sea-level rise of $1.0 \mathrm{~mm}$ per year. After Harff and Meyer (2007, Fig. 14). Reproduced with permission

followed a different history, and the processes affecting the preservation and visibility of shoreline features and archaeological material, or their destruction, are different.

At the present day, the coastline is one of offshore barrier islands, tidal mudflats and coastal marshes, with one of the world's largest continuous mud-flat areas, up to $40 \mathrm{~km}$ wide-the Wadden Sea (Wattenmeer in German, Waddenzee in Dutch and Vadehavet in Danish), so named because of the ability to 'wade' through the mud at low tide. This zone is regularly inundated and then exposed again in an approximately 6-hour tidal rhythm. The tidal range, and hence the width of the intertidal zone and its impact on the potential for destruction or burial of onshore features, varies from $1.5 \mathrm{~m}$ in the north (North Friesland) to $4 \mathrm{~m}$ on the Lower Saxony coast (Fig. 5.5; Behre 2003). Storm surges can further amplify the destructive effects of marine inundation. They are no more frequent than on the Baltic coast, but the wave fetch is much larger, extending for hun- dreds of kilometres out into the North Sea, and generates waves more than twice as high as in the Baltic (Policy Research Corporation 2009). These destructive effects are mitigated by barrier islands formed by erosion and redeposition of earlier sediments, which can create bays and lagoons protected to some extent from the full force of waves in the open sea.

When sea level was at its lowest, land extended more than $300 \mathrm{~km}$ to the north and west of the modern German coastline, an area that has come to be known as Doggerland (Coles 1998), named after the area of the Dogger Bank, which would have formed a low hill within an otherwise lowland plain of limited relief, with lakes, marshes and river channels, especially those created by the extension of major rivers such as the Rhine, the Elbe and their various tributaries. A combination of seismic surveys, geophysical modelling of eustatic sea-level rise in relation to isostatic warping of the Earth's crust and coring of sediments has provided considerable detail, if patchily dis- 
A

$\mathrm{m} / \mathrm{ms}$

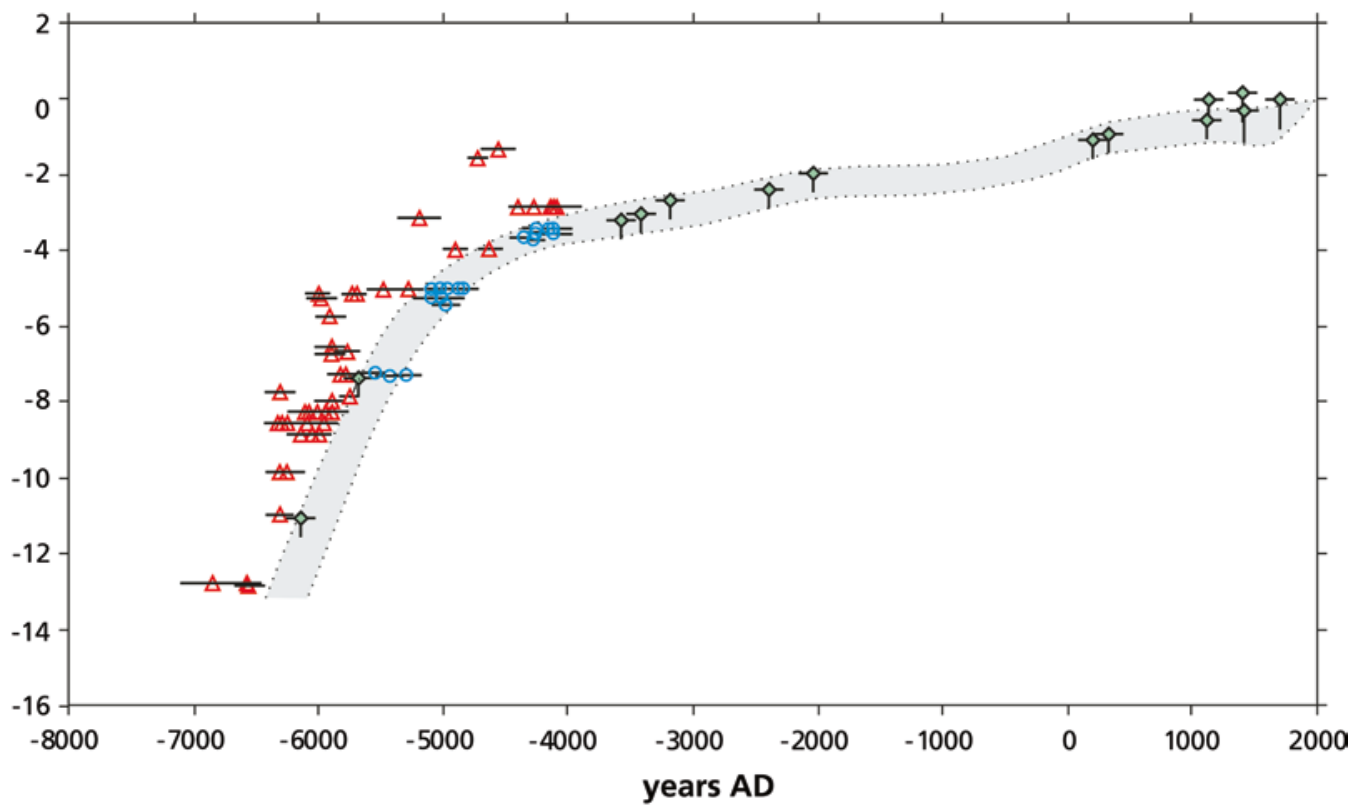

B

$\mathrm{m} / \mathrm{ms}$

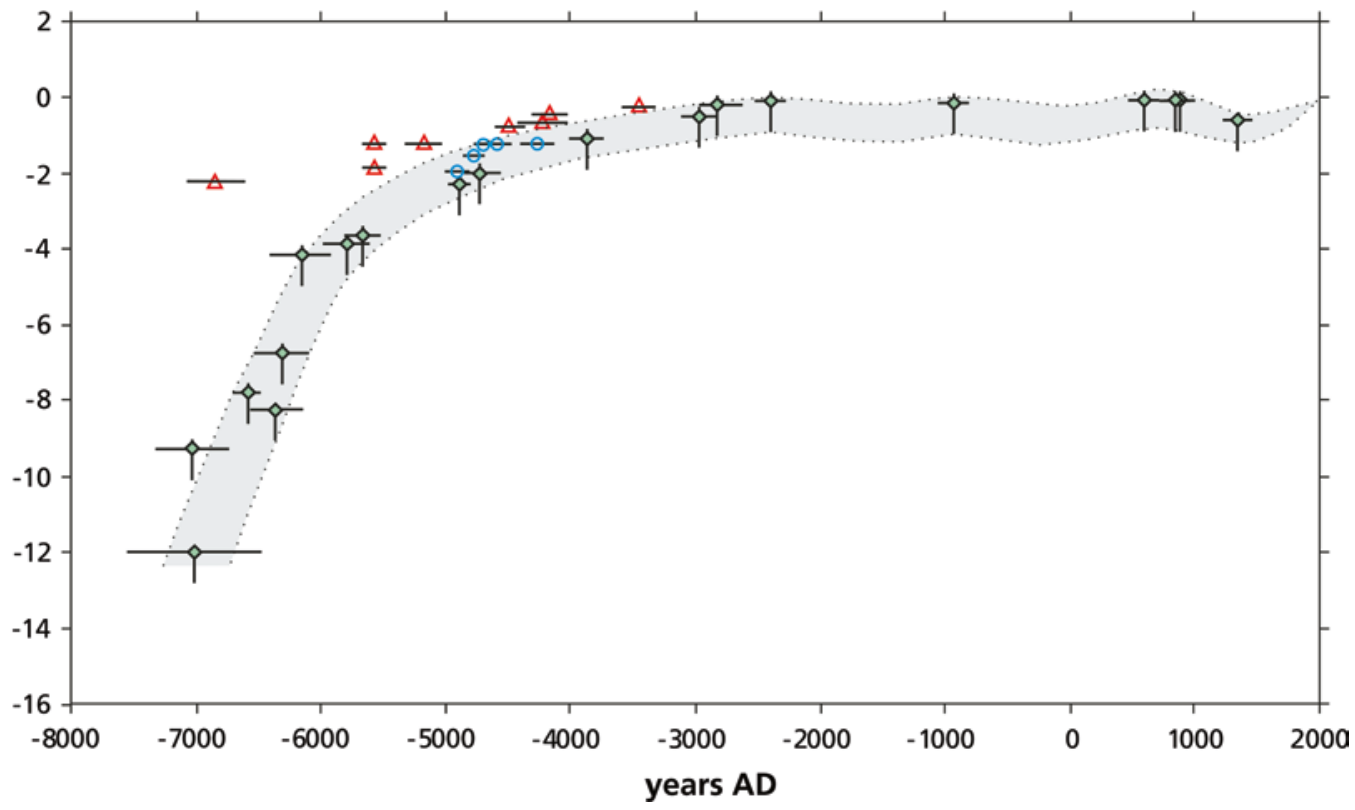

Fig. 5.3 Radiocarbon-dated relative sea-level curves for the Wismar Bight (a) and north Rügen/Hiddensee (b). Red triangles: terrestrial deposits; green diamonds, peat deposits; blue circles, archaeological finds in marine nearshore deposits. Horizontal bars represent $2 \sigma$, vertical bars indicate estimated vertical error of sea level position. After Lampe (2007, Fig. 4). Reproduced with permission 
1

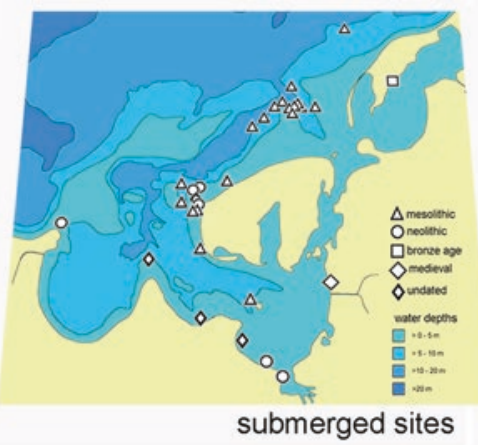

3

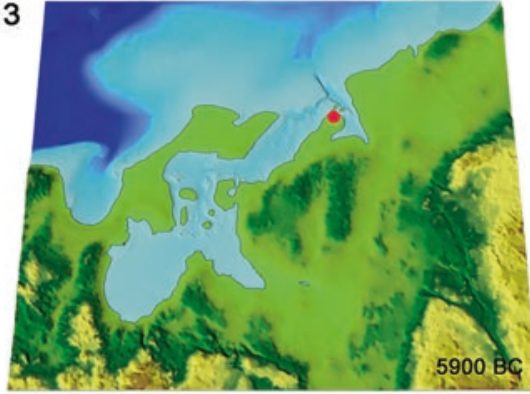

-Jäckelgrund-Orth

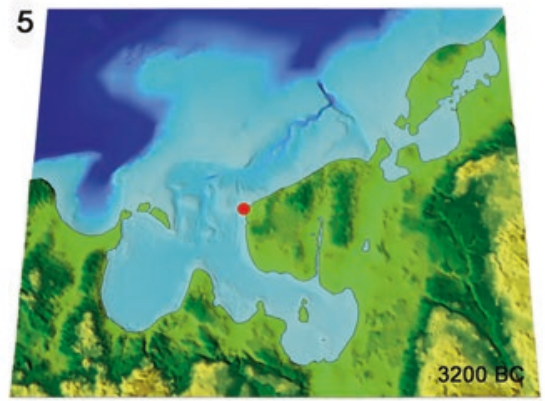

-Timmendorf-Tonnenhaken

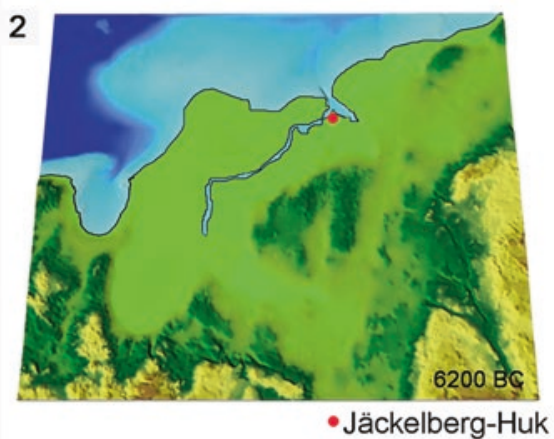

4

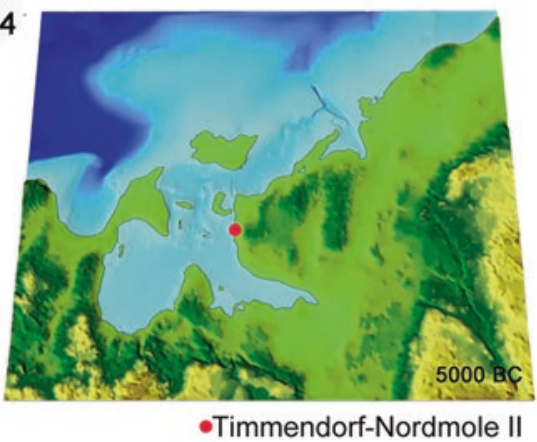

6

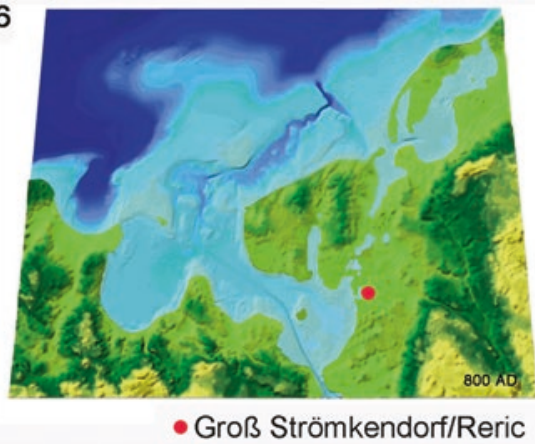

Fig. 5.4 Series of maps showing the changing configuration of shorelines and the locations of submerged archaeological sites in the Wismar Bight at different stages of marine transgression from the late seventh millennium $\mathrm{BC}$ to the first millennium AD. 1: location and date of sites and bathymetry; 2, $6200 \mathrm{cal} \mathrm{BC;} 3,5900 \mathrm{cal} \mathrm{BC;} \mathrm{4,} 5000 \mathrm{cal} \mathrm{BC}$; 5, $3200 \mathrm{cal} \mathrm{BC;} \mathrm{6,} \mathrm{AD} \mathrm{800.} \mathrm{After} \mathrm{Jöns} 2011$

tributed, about these topographic and environmental features and how they changed with progressive sea-level rise (Shennan et al. 2000, Streif 2004; Cohen et al. 2017 and references therein; see also Peeters and Amkreutz, Chap. 8; Bailey et al., Chap. 10, this volume). In the German sector, geophysical survey and coring have recently mapped the course of the Ems River offshore, showing that it was a meandering tributary of the Elbe River, with a width of 500-1500 m and a channel depth of 7-14 m cutting into the Pleistocene deposits below the seafloor (Hepp et al. 2017).

Information on vegetation development across Doggerland is at present still fragmentary. This is particularly true for the LGM. Deposits of this date suitable for vegetation reconstruction have 


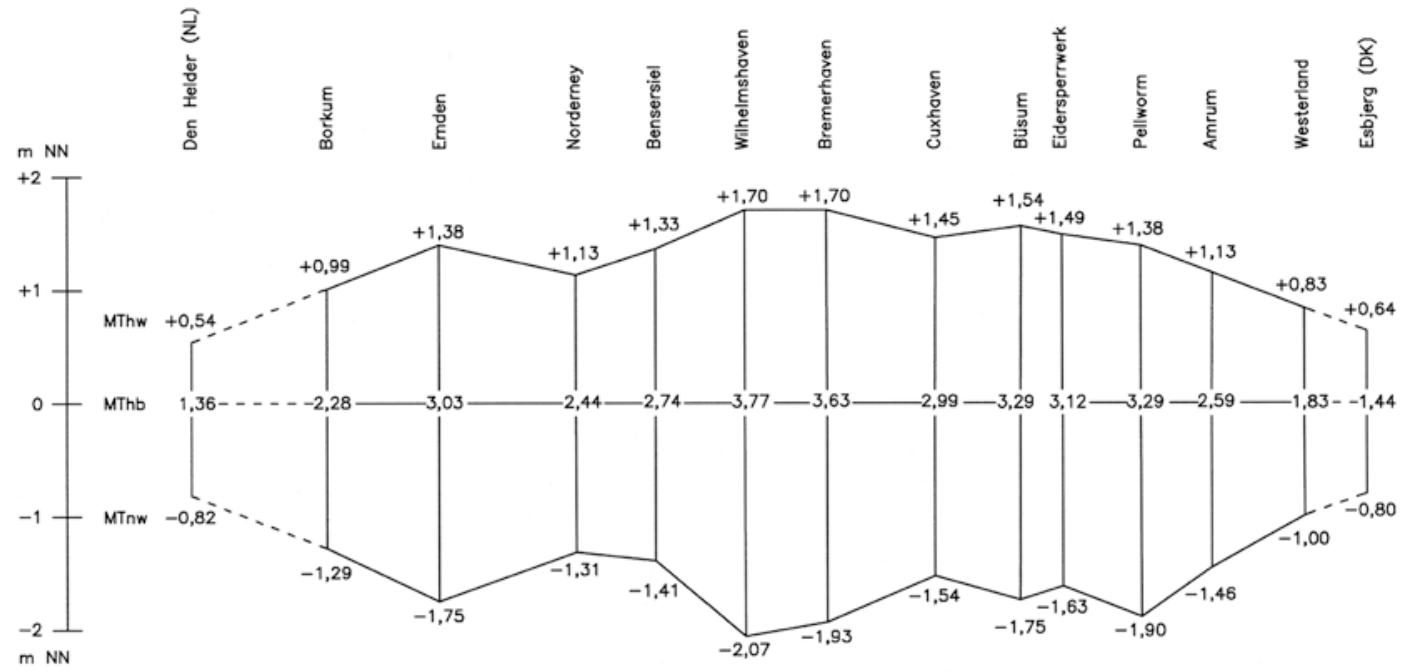

Fig. 5.5 Diagram showing variation in tidal range along the North Sea coastline from the Netherlands border in the SW (Die Helder at left of diagram) to the Danish border in the NE (Esbjerg at right of diagram). Note that the tidal range (MThb) is greatest in the central sector of the Lower Saxony coastline near the estuaries of the Weser and Elbe Rivers, and steadily reduces in both direction, in the island areas of East Frisia (Borcum to Bensersiel) and North Frisia (Büsum to Westerland). MThw: mean high water mark; MTnw, mean low water mark. After Behre (2003, Fig. 1). Reproduced with permission

not so far been investigated. Vegetation records from Late Glacial sediments are rare (Krüger et al. 2017; Brown et al. 2018). However, there is a better record for the Holocene. Thanks to climatic warming at the onset of the Holocene (c. 11,600 cal $\mathrm{BP}$ ) and the influence of a continuously rising sea level, fen peat growth on the present-day seafloor commenced on a large scale, and palynological analysis of sediment cores from these peat sequences has produced an early Holocene record of the vegetation development on Doggerland (e.g. Behre and Menke 1969; Behre et al. 1984; Gearey et al. 2017; Wolters 2009; Wolters et al. 2010). The vegetation succession follows the general trend observed on the present-day mainland, with the development of pine-birch forests interspersed with aspen from c. 11,600 cal BP followed by expansion of hazel at around 10,700 cal BP and the successive spread of the typical deciduous elements of the mixed oak forest, such as elm (Ulmus sp.), oak (Quercus sp.), lime (Tilia sp.) and ash (Fraxinus sp.). Habitats close to the groundwater table were mostly occupied by eutrophic carr vegetation with willow (Salix sp.) and later mostly alder (Alnus sp.).
Between c. 21,000 and 8400 cal BP $(19,000-$ 6400 cal BC), sea level rose steadily and at an accelerating rate from a glacial lowstand of c. $-130 \mathrm{~m}$ to $-25 \mathrm{~m}$ (Fig. 5.6; Behre 2003, 2007; Streif 2004). During this period, the shoreline continuously shifted landwards with erosion of pre-existing shoreline features such as low cliffs and sand barriers, followed by deposition of fluvial and marine sediments. After about $8000 \mathrm{cal}$ BP (6000 cal BC), the rate of sea-level rise slowed down considerably, continuing to rise slowly up to the present day. During this period the shoreline was subject to a series of minor regressions and transgressions, the regressions occurring during periods when the growth of peat bogs outpaced the long-term trend of sea-level rise. Thick sediments as much as $25 \mathrm{~m}$ thick or more also accumulated during this period, comprising complex and laterally variable sequences of peat, intertidal, brackish-lagoonal, alluvial and marine sediments.

Throughout the period of sea-level rise, the coastal landscape most likely comprised some combination of sand barriers, intertidal mudflats and coastal marshes. In the earlier part of the 


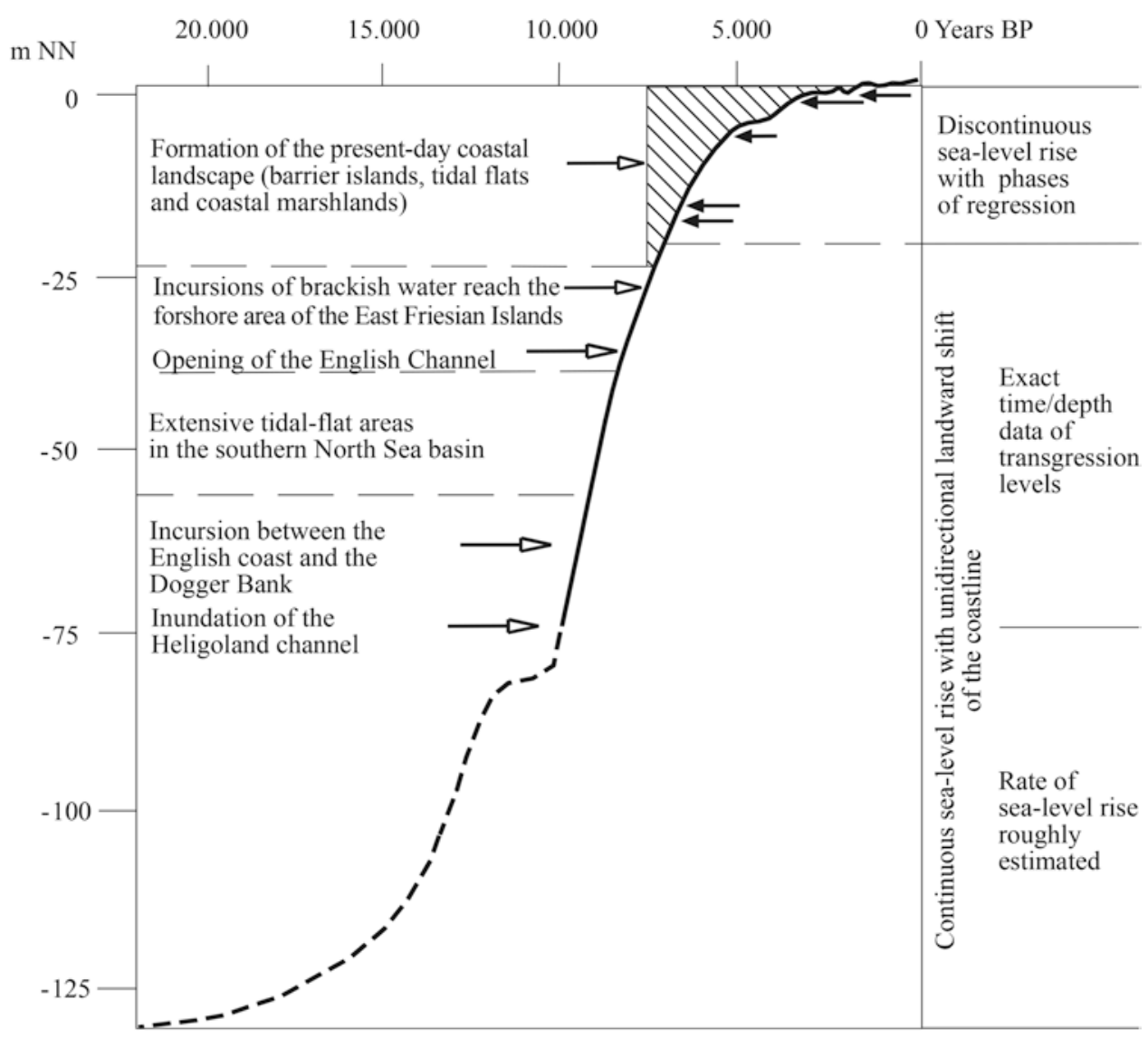

Fig. 5.6 Time/depth diagram of sea-level rise on the North Sea coastline of Germany from its lowstand during the Last Glacial Maximum to the present day. Depth is related to the German Ordnance Datum, NN, which is close to mean sea level. Note that ages are given in conventional radiocarbon years BP. Approximate conversion to cal BP is as follows: $20,000=23,930 ; 15,000=18,250 ; 10,000=11,550 ; 5000=5760$. After Streif $(2004$, Fig. 3). Reproduced with permission

marine transgression when sea-level rise was relatively rapid, sediment sequences would have been disturbed by erosion and redeposition, resulting in a fragmentary record. Elevated features such as levees along river courses and barriers of sand along the coast would have provided attractive places for human settlement, but equally these features would have been vulnerable to destruction by erosion or hidden from view by burial under subsequent accumulations of sediment. During the Holocene, the reduced rate of sea-level rise and the accumulation of thick layers of sediment produced a smooth and shallow offshore gradient with extensive tidal mudflats, though not necessarily with the same character as the present-day Wadden Sea, because prior to the building of dykes, the coastline was constantly changing as a result of repeated transgressions and regressions (Jöns et al. 2013).

\subsection{Archaeological Context and Underwater Sites}

The northern German lowland was partly covered by ice during the LGM and uninhabited until the Late Glacial period, when ameliorating climatic conditions allowed reindeer hunters of the Hamburgian and Ahrensburgian cultures to enter the region (Table 5.1). Red flint from Heligoland 
Table 5.1 Chronological chart showing archaeological periods in the German coastal areas and neighbouring countries. After Hartz and Lübke (2006), Niekus (2006) and Müller et al. (2010). Yellow: late Palaeolithic; green, Mesolithic; blue, Neolithic. Graphics by Svea Mahlstedt NIhK

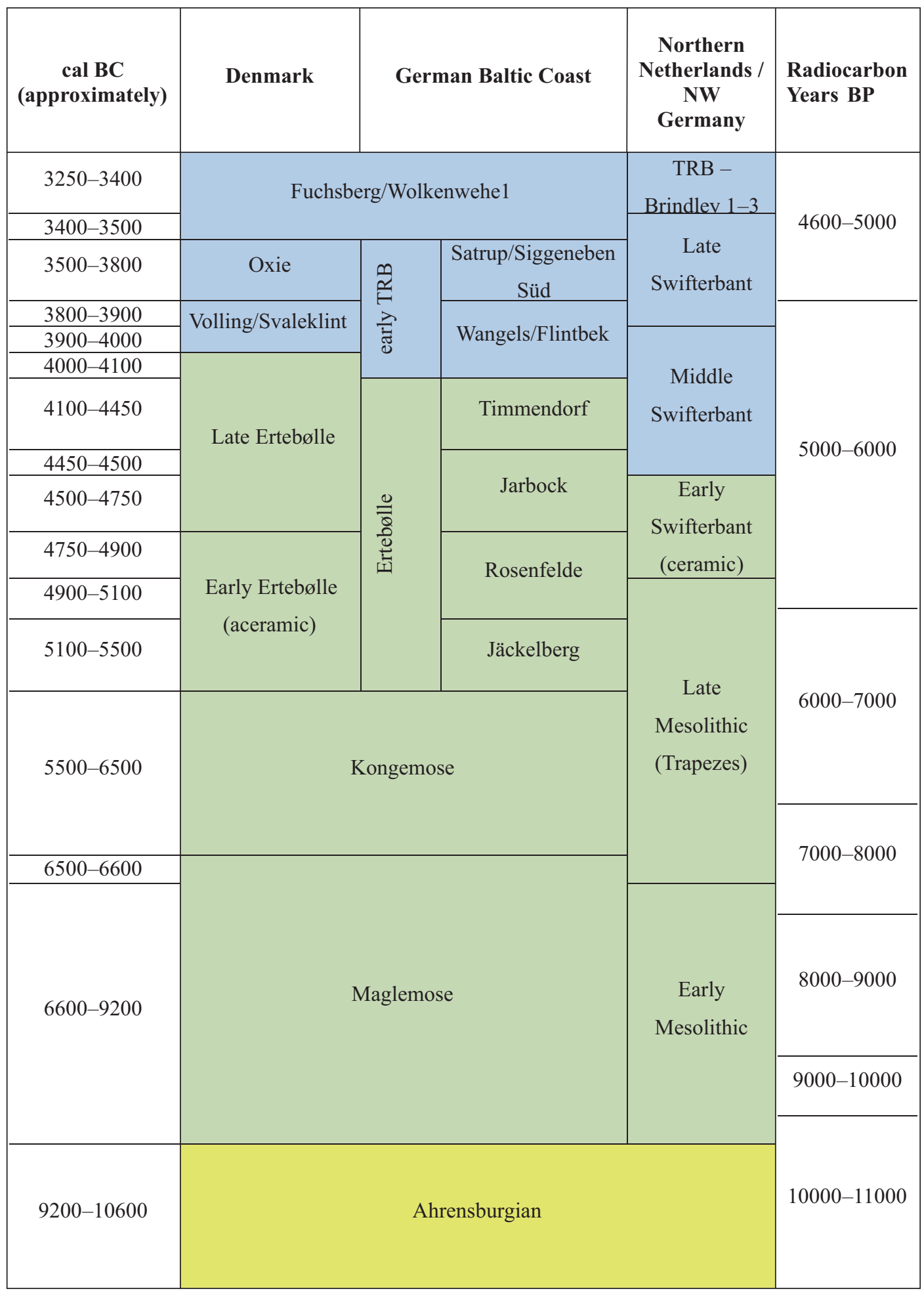


was exploited by these groups, and artefacts made of this raw material are found in the northern German hinterland some $200 \mathrm{~km}$ distant from the source, demonstrating movements out onto the now-submerged North Sea area (Fig. 5.7; Fries and Veil 2014).

With reforestation, Mesolithic huntergatherers became established in the region (Grimm et al. (2020), and the sequence can be structured into several phases with some variation between the Baltic and the Wadden Sea coastal regions. The Mesolithic cultural sequence on the Baltic coast is comparable to Denmark with Maglemose, Kongemose and Ertebølle culture periods-Early, Middle and Late Mesolithic, respectively (Brinch Petersen 1967, 1973; Holst 2014; see also Bailey et al.,
Chap. 3, Table 3.1, this volume, and Nilsson et al. Chap. 4, this volume). Information on the Late Mesolithic comes mostly from underwater sites, and the quality and detail of evidence have allowed a high-resolution chronology and further subdivision into cultural sub-phases (Table 5.1; Hartz and Lübke 2006).

In north-western Germany on the North Sea side, the sequence is similar to the Netherlands with Early and Late Mesolithic phases (Lanting and Van der Plicht 2000; Niekus 2006, Mahlstedt 2015), followed by material with similarities to the Swifterbant (Stapel 1991; Raemaekers 1999; Ten Anscher 2015). The Swifterbant, like the Late Ertebølle to the north, is a Mesolithic culture with ceramics. In the Netherlands it began earlier than the ceramic Ertebølle; conversely
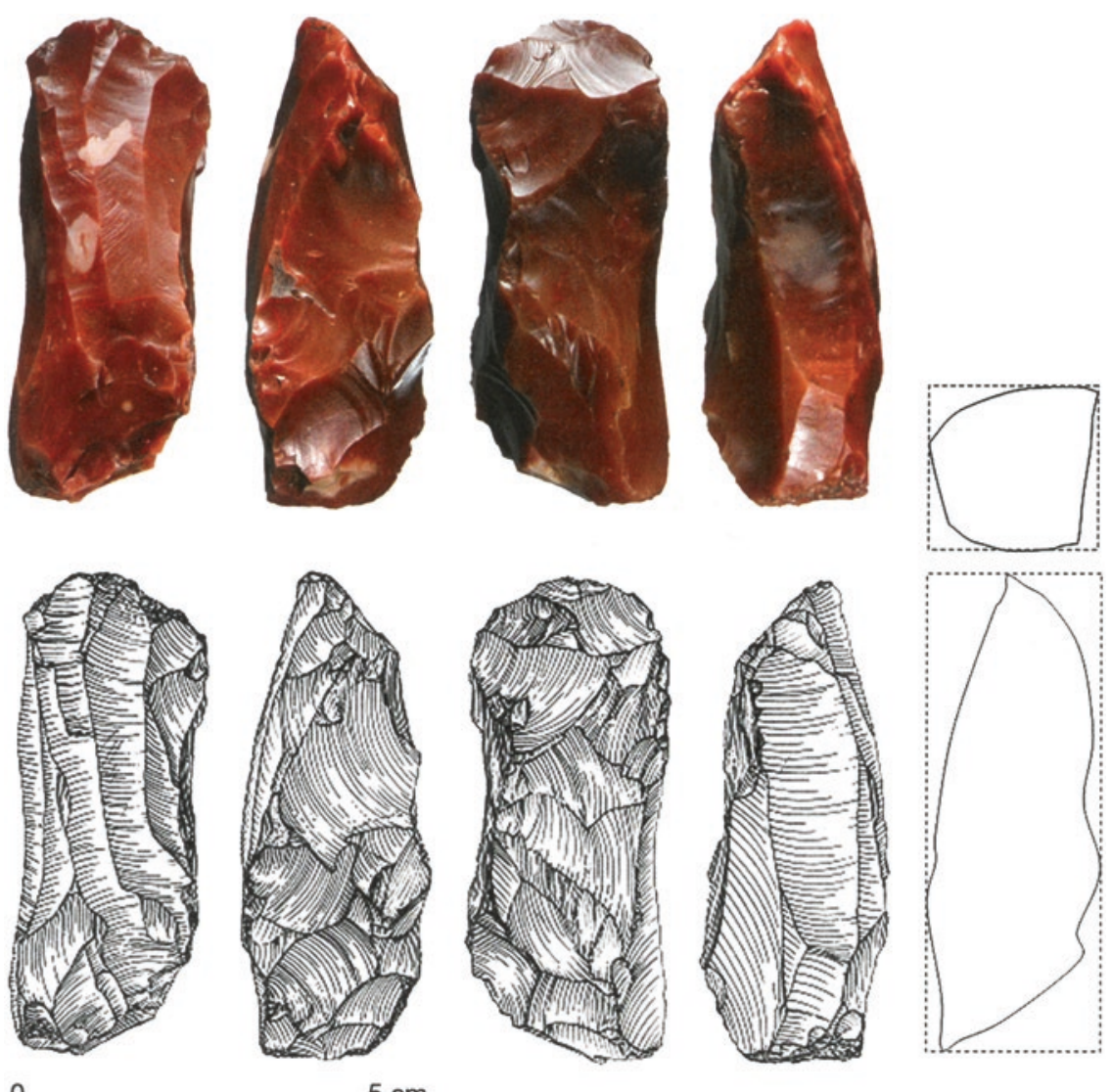

0

$5 \mathrm{~cm}$

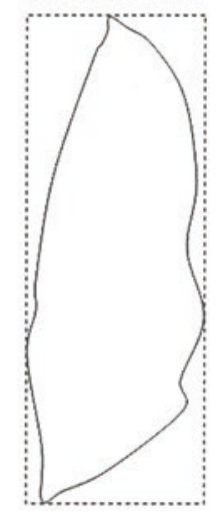

Fig. 5.7 The find of a Late Palaeolithic core made of typical red Heligoland flint found in Damme, district of Vechta, proves that the island was still connected to the mainland at the time. After Fries and Veil 2014, Fig. 3 
Neolithisation took place earlier in the German Baltic region, where it is associated with the Early Funnel Beaker culture.

The currently known underwater finds are shown in Table 5.2. The majority (100) are from the Baltic and occur in water depths of $2-10 \mathrm{~m}$. Mesolithic and Neolithic sites dominate (47\% and $24 \%$, respectively), and this reflects in part the fact that systematic survey in the Baltic region concentrated on these periods of the sequence, in part on the fact that sites in this depth range are the most easily accessible to underwater investigation. In situ cultural material from settlements is relatively rare (18\%), the remaining sites comprising mainly collections of unstratified material (49\%) or single finds $(31 \%)$.

\subsection{Sites on the Baltic Coast}

Underwater research here has mainly focussed on the period of the Littorina transgression from 6000 to $2000 \mathrm{cal} \mathrm{BC}$, when the people living in the maritime zone between the Oder estuary and the Flensburg Fjord had to adapt to a continuously rising sea level and a shifting shoreline (see Fig. 5.4). Many of the sites were discovered by the SINCOS project, which concentrated on systematic survey in two areas, the Wismar Bay in the west and the coastal waters around Rügen Island in the east (Fig. 5.1). Fieldwork was restricted to sites of Late Mesolithic and Neolithic date in order to focus on the nature of human response to the Littorina transgression. In both research areas, systematic geophysical survey led to the discovery of numerous settlements located on palaeoshorelines. All available information about these finds was recorded in the SINCOS database, providing both a series of sea-level index points for the reconstruction of sea-level rise and the basis for further archaeological investigation.

Some of these sites offer exceptional conditions for the preservation of organic material, and artefacts of wood, bone and antler as well as flint tools were recovered in large quantities during excavations, together with other settlement features such as remains of timber structures and hearth areas.

\subsubsection{Wismar Bay}

One of the most important concentrations of sites is in the Wismar Bight, where well-preserved archaeological deposits were discovered, some of which have been excavated (Jöns et al. 2007; Hartz et al. 2011; Lübke et al. 2011). A systematic programme of joint geophysical and archaeological survey was able to identify a succession of palaeoshorelines and archaeological sites associated with progressive marine transgression and transformation from freshwater to fully marine conditions (see Fig. 5.4). Here we describe the key excavations in chronological order starting with the earliest.

The oldest site is Jäckelberg-Huk on the north side of the present-day island of Poel, found at a depth of $8.5 \mathrm{~m}$ below present sea level (bpsl) and radiocarbon-dated between 6400 and 6000 cal BC (Hartz et al. 2011, pp. 94-104). Here an area of $31 \mathrm{~m}^{2}$ was excavated and revealed part of a cultural layer sealed beneath peat and marine sediments, with remains of two hearths indicated by fire-cracked stones. Microlithic flint arrowheads comprise rhombic forms typical of the Early Kongemose culture, consistent with the radiocarbon dates (Sørensen 2017; Bailey et al. Chap. 3, Table 3.1, this volume). Faunal remains are dominated by bones of freshwater fish such as perch (Perca fluviatilis) and pike (Esox lucius) or migratory species, notably European eel (Anguilla anguilla), indicating a location next to a lake at this time (Table 5.3; Schmölcke et al. 2007). Remains of land mammals include red deer (Cervus elaphus), roe deer (Capreolus capreolus) and wild boar (Sus scrofa).

The nearby site of Jäckelgrund-Orth is slightly younger in age, discovered at a depth of $7-8 \mathrm{~m}$ bpsl in association with tree stumps radiocarbon dated at 6000 to $5700 \mathrm{cal} \mathrm{BC} \mathrm{(Jöns} \mathrm{et} \mathrm{al.}$ 2007). Only terrestrial fauna was present here. Jäckelberg-Nord, dated at c. $5200 \mathrm{cal} \mathrm{BC}$, produced a small faunal assemblage with bones of red deer (Cervus elaphus) and boar (Sus scrofa), while the fish bones show the first appearance of marine species such as cod (Gadus morhua), herring (Clupea harengus), flatfish (Pleuronectidae) and garfish (Belone belone) alongside freshwater species (Hartz et al. 2011, pp. 110-111, Table 10). 


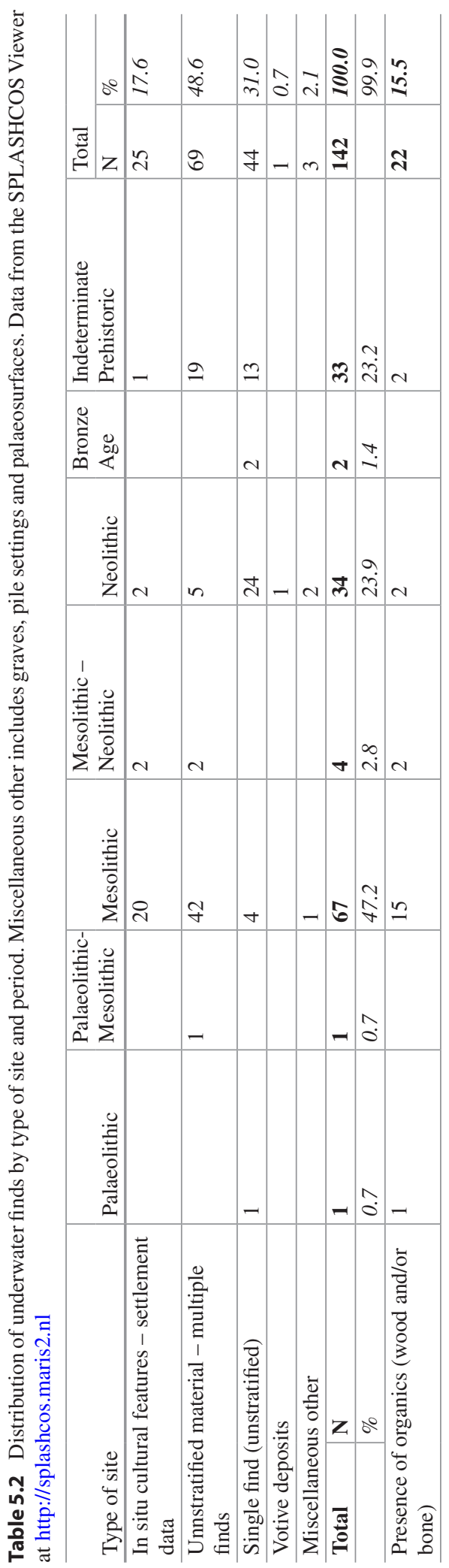


Table 5.3 Faunal remains from Poel 42 and Jäckelberg-Huk (6300-6000 cal BC). Numbers of identified animal bones (NISP) and their percentage frequency. The fish species are classified as marine (M), migratory (F/M) and freshwater (F). After Hartz et al. (2011, Table 5)

\begin{tabular}{l|r|l|l|l|l}
\hline Fish & NISP & $\%$ & Mammal & NISP & $\%$ \\
\hline Perca fluviatilis $(\mathrm{F})$ & 1340 & 61.0 & Arvicola terrestris & 37 & 45.1 \\
\hline Esox lucius $(\mathrm{F})$ & 386 & 17.6 & Cervus elaphus & 22 & 26.8 \\
\hline Cyprinidae $(\mathrm{F})$ & 304 & 13.8 & Capreolus capreolus & 13 & 15.9 \\
\hline (Tinca tinca & 3 & $0.1)$ & Sus scrofa & 2 & 2.4 \\
\hline (Rutilus rutilus & 5 & $0.2)$ & Erinacaeus europaeus & 2 & 2.4 \\
\hline (Scardinius erythrophthalmus & 2 & $0.1)$ & Felis silvestris & 2 & 2.4 \\
\hline Anguilla anguilla $(\mathrm{F} / \mathrm{M})$ & 122 & 5.6 & Phocidae & 2 & 2.4 \\
\hline Pleuronectidae $(\mathrm{M})$ & 7 & 0.3 & (Halichoerus grypus & 1 ) & 1.2 \\
\hline Gadus morhua $(\mathrm{M})$ & 4 & 0.2 & Bos primigenius & 1 & 1.2 \\
\hline Coregonus sp. $(\mathrm{F} / \mathrm{M})$ & 24 & 1.1 & & & \\
\hline Total & $\mathbf{2 1 9 7}$ & $\mathbf{1 0 0}$ & & $\mathbf{8 2}$ & $\mathbf{9 9 . 8}$ \\
\hline
\end{tabular}

The site of Timmendorf-Nordmole II is located only a few kilometres south of Jäckelberg at a depth of $5 \mathrm{~m}$ bpsl. Excavation over an area of $12 \mathrm{~m}^{2}$ revealed a land surface alongside the edge of a stream bed. The stream bed had been filled with fluvial and estuarine sediments and peat, and the land surface had been partly covered and sealed by these deposits. Most of the finds were found in the marine sediments of the stream fill where preservation conditions for organic material were excellent, with recovery of wooden artefacts including several leister prongs and remains of a fish weir originally built across the mouth of the stream. Analysis of the material culture indicates that the site belongs to an aceramic phase of the Ertebølle culture, and radiocarbon dates place the main cultural layer between 5100 and 4800 cal BC (Hartz and Lübke 2006; Hartz et al. 2011, p. 111). By this period, marine species were dominant in the fish-bone assemblage (80\%), with migratory eel dominating alongside cod and mackerel (Scomber scombrus). Beneath this main cultural layer, a second, smaller culture layer was found containing mammal bones dated to 5900-5600 cal BC. On the terrestrial surface of the adjacent shore and sealed beneath peat and marine sediment, there was a hearth area comprising a concentration of charcoal and white ash dated to c. 5400 cal BC (Jöns et al. 2007, p. 99, Table 2).

The neighbouring site of TimmendorfNordmole I is also of great scientific interest, representing an extensive scatter of cultural remains over an area some $250 \mathrm{~m} \times 100 \mathrm{~m}$ at a depth of 2.5-3.5 m bpsl. The site was originally located on the shore of an inlet with a settlement area on dry land and an offshore 'dump' area in shallow water, similar to the locations of some of the underwater sites in Denmark (see Bailey et al., Chap. 3, this volume). Three trenches covering a total area of c. $42 \mathrm{~m}^{2}$ were excavated, including part of the shore zone on former dry land and the offshore dump zone (Hartz et al. 2011, pp. 121-127, and references therein). Artefacts were also found scattered on the surrounding surfaces. The cultural material belongs mostly to the Late Ertebølle culture with radiocarbon dates between c. 4400 and $4100 \mathrm{cal} \mathrm{BC}$. The settlement surface on dry land had been badly eroded by subsequent marine inundation, but in one location a pit, $3.5 \mathrm{~m} \times 1.8 \mathrm{~m}$ at its surface and $0.9 \mathrm{~m}$ deep, had survived the effects of erosion. The pit contained a number of logs and poles thought to be the remains of a collapsed roof structure (Fig. 5.8), but the pit appears to be too small to represent a pit dwelling. The sediment fill contained numerous artefacts including a truncated blade hafted at right angles to a hazelwood handle with a binding of thin twisted cord and lime bast (Fig. 5.9; Lübke 2001, 2003). Elsewhere, the culture layer extended offshore with layers of peat and palaeosols sealed beneath marine sand. These contained numerous unpatinated flint artefacts, animal bones, wooden 


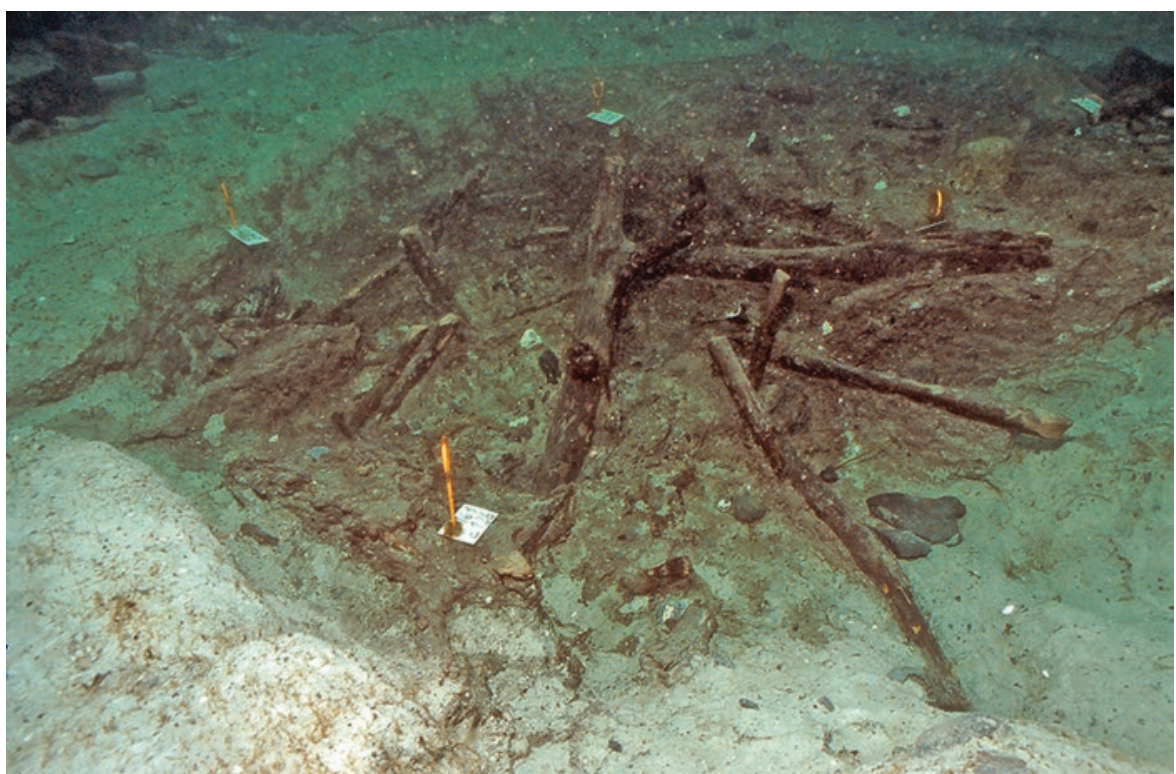

Fig. 5.8 The pit at Timmendorf-Nordmole I in Wismar Bay with the timbers of a collapsed wooden structure. Photo courtesy of State Heritage Agency of Mecklenburg-West Pomerania

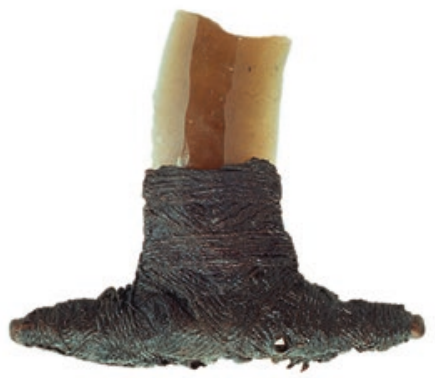

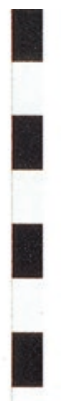

b

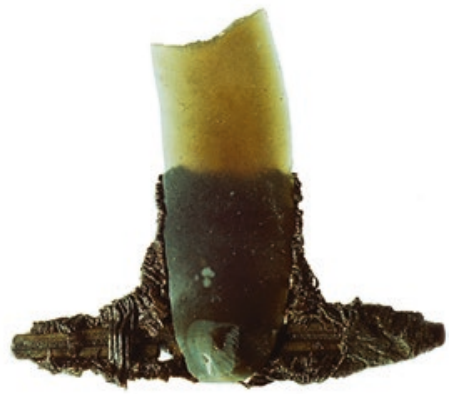

C

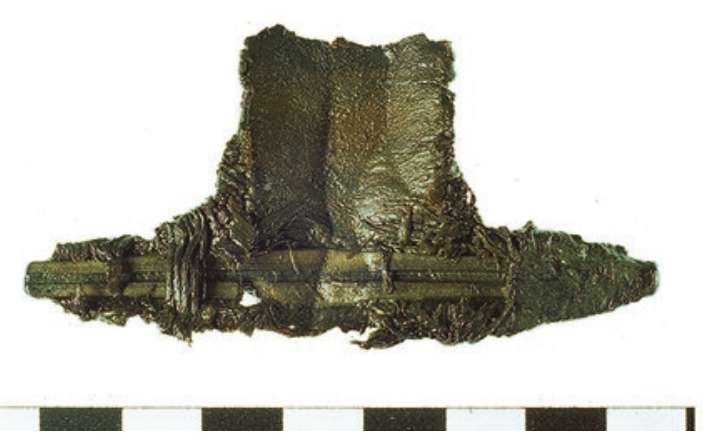

Fig. 5.9 Truncated flint blade hafted in a hazelwood handle, found at Timmendorf-Nordmole I, showing details of the cordage and lime bast used to attach the flint to the handle. A: dorsal surface; B, ventral surface; C, closeup of ventral surface. Scale in centimetres. Photo by Sabine Suhr, State Heritage Agency of Mecklenburg-West Pomerania 
artefacts including leister prongs and logboat fragments and a small number of Ertebølle potsherds, some with charred food crusts. Here too, eel is a dominant species in the faunal remains with some cod and flatfish. Terrestrial fauna is also present, and the site has been interpreted as a specialist site for terrestrial-game hunting and eel fishing (Hartz et al. 2011, pp. 126-127).

Another site nearby discovered at $2 \mathrm{~m}$ bpsl is Timmendorf-Tonnenhaken, located on a former peninsula. Here a cultural layer with wellpreserved artefacts made of stone, bone and antler was recovered as well as potsherds of the Early Neolithic Funnel Beaker culture. The latter are consistent with radiocarbon dates of c. 3200 and 2700 cal $\mathrm{BC}$ and the fact that all the bone material is from domesticated animals such as cattle and pigs (Lübke 2002).

This combination of sites is important in a number of ways. It provides a detailed reconstruction of development from the Late Mesolithic to the Early Neolithic between 6000 and $4000 \mathrm{cal} \mathrm{BC}$ for the region. It documents the progressive encroachment of the sea on the land and the pattern of shifting coastlines associated with the Littorina transgression (see Fig. 5.4). Moreover, this spatial separation of sites enforced by moving shorelines has allowed the reconstruction of a more detailed chronological subdivision of the material culture than would otherwise have been the case. The abundant faunal remains also demonstrate the importance of marine resources alongside terrestrial hunting and the progressive shift from freshwater to marine species with rising sea level (Schmölcke et al. 2007; Lübke et al. 2011). Shoreline locations were important for the Mesolithic settlements, especially on the banks of inlets, where fish could be easily trapped, but remained important during the Early Neolithic, when the economy had become more dependent on domestic animals.

\subsubsection{Wooden Artefacts}

Most of the wooden artefacts in the Wismar Bay excavations are associated with fishing, perhaps reflecting the fact that they were discovered in what were originally shallow water areas close to the shoreline where such material would most likely have been concentrated and well preserved (Klooß 2015). The most common items are sections of roundwood, sometimes with the remains of the cordage used to tie them together, leister prongs, again with remains of cordage showing how they were tied together to form leister spears most likely used for eel fishing, fragments of basketry from fish traps and paddles (Fig. 5.10). Some wooden items are thought to be the remains of fish weirs, and fragments of logboats have also been recovered. Wooden handles for antler and ground stone axes have also been found, and the distinctive hafted implement referred to above (see Fig. 5.9) and found in the pit fill at Timmendorf-Nordmole I.

The manufacture of the wooden tools implies detailed knowledge of the different types of trees appropriate to different purposes and skill in woodland management, especially the coppicing of hazel to produce straight and uniform rods.

\subsubsection{Rügen}

Research on the Late Mesolithic and Early Neolithic cultures of Rügen Island and the coastal areas of the adjacent mainland reaches back to the early twentieth century (Terberger 2007, p. 241; Hartz et al. 2011, p. 135). Early discoveries included numerous lithic and organic artefacts, several human skulls and artefacts of central European provenience dredged up from the seafloor, material attributed to a regional variant of the Ertebølle Culture, known as the Lietzow Culture, and indicating good prospects for the recovery of well-preserved underwater cultural deposits. In 2002, the SINCOS project began a programme of research on the existing archives of material, AMS radiocarbon dating and new underwater geophysical survey and excavation (summarised in Jöns et al. 2007, p. 153; Hartz et al. 2011).

By coincidence, large-scale rescue excavations by the state heritage authorities took place in advance of construction work in Stralsund City and at Baabe on Rügen Island over the same period as the SINCOS project. These produced abundant additional evidence of coastal sites and sea-level rise in the period 5500 to $3500 \mathrm{cal} \mathrm{BC}$, 

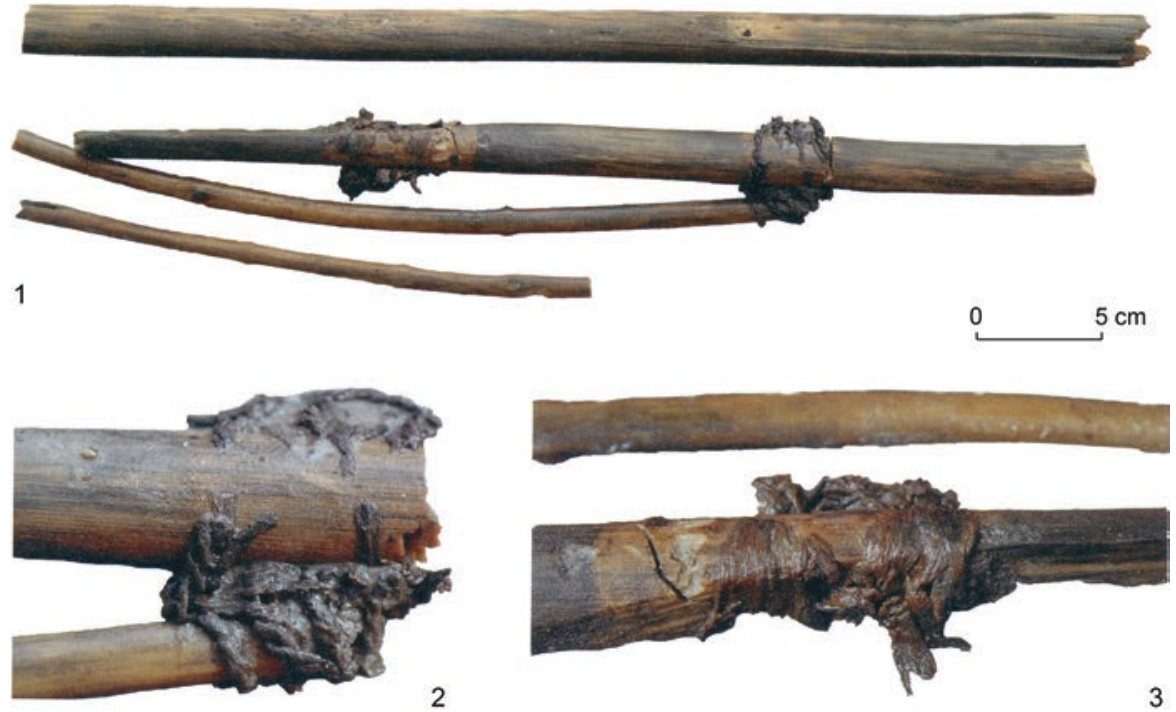

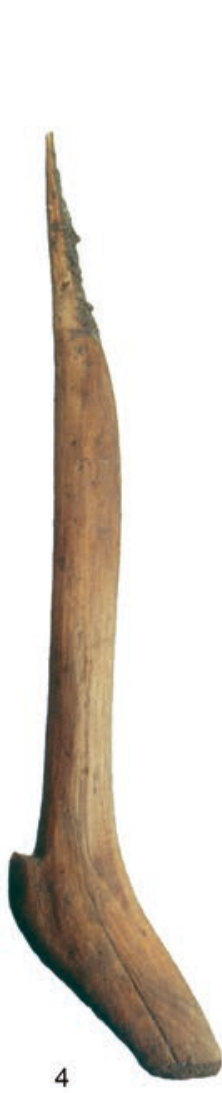

0

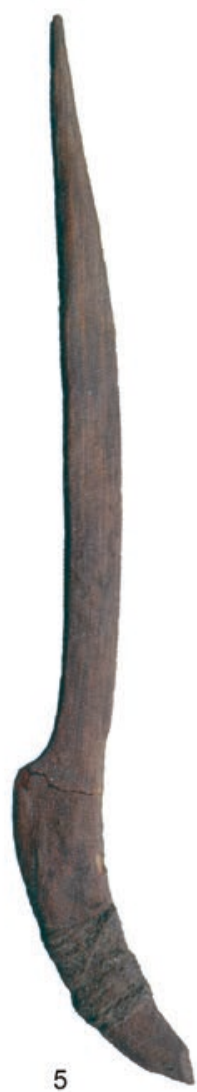

$5 \mathrm{~cm}$
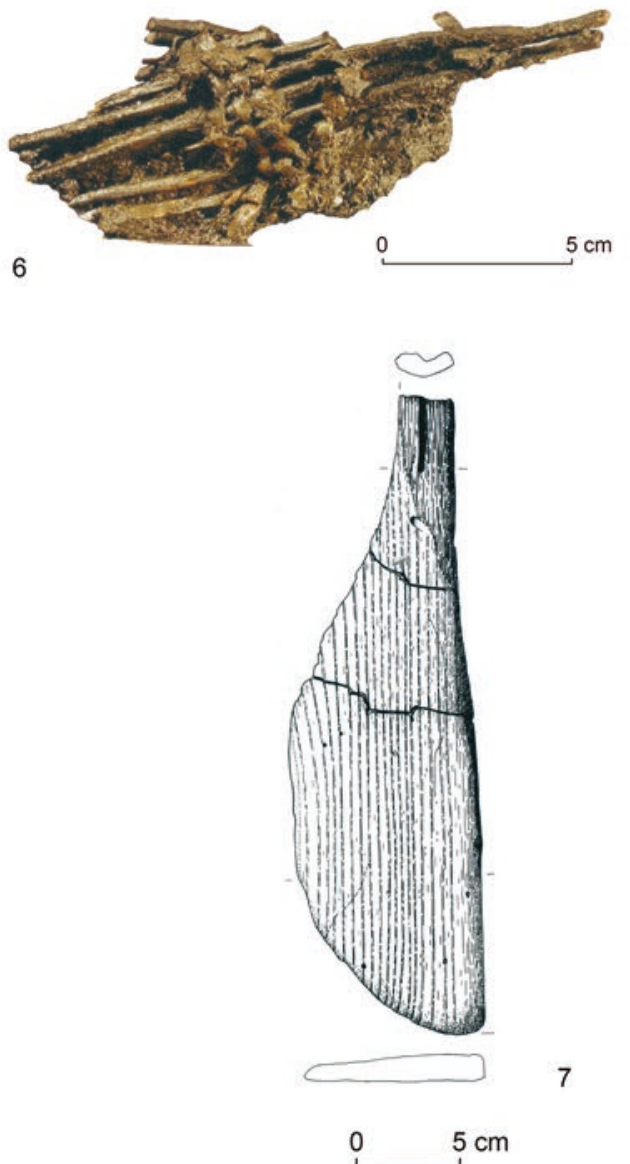

Fig. 5.10 Selection of wooden artefacts from the Timmendorf-Nordmole (T-N) sites of Wismar Bay. 1-3: wooden artefacts from T-N III showing use of cordage to bind pieces together (after Klooß 2015, Figs. 290-291); 4-5, leister prongs from T-N I and III, the right-hand specimen with remains of binding residue (after Klooß 2015, Fig. 288 a, b); 6, fragment of a wicker-work fish-trap from T-N II (after Klooß 2015, Fig. 154); 7, paddle from T-N 1 (after Klooß 2015, Taf. 36, 1). Reproduced with permission 
results that the SINCOS project was able to integrate with its own research.

Despite poor underwater visibility because of algae growth, 15 underwater sites were discovered by the SINCOS project, some with excellent preservation of culture layers, and two were excavated, Kamminer Ort (Wittow 100, Ostsee VI) and Breetzer Ort (Bergen 24, Ostsee VI).

At Kamminer Ort, many artefacts and animal bones were discovered embedded in layers of peat and marine gyttja, dating to the period between 4900 and 4700 cal. BC. Animal bones included boar (Sus scrofa), red deer (Cervus elaphus), roe deer (Capreolus capreolus) and pine marten (Martes martes), freshwater fish such as perch (Perca sp.), pike (Esox lucius) and cyprinids (Cyprinidae), and bottom-dwelling marine species such as flatfish (Pleuronectidae) and eelpout (Zoarces viviparus).

At Breetzer Ort, excavation campaigns in 2004, 2007 and 2008 demonstrated the presence of three phases of occupation: Late Mesolithic (c. 5600-5500 cal BC), Terminal Mesolithic and Middle Ertebølle (c. 4800-4500 cal BC) and Final Mesolithic (4200-4100 cal BC). During this 1500 -year period, the site underwent progressive inundation by sea-level rise during the Littorina transgression. A Late Mesolithic fire place submerged at about $5000 \mathrm{cal} \mathrm{BC}$ remained intact because of protection by two collapsed oak trunks. At c. $4800 \mathrm{cal} \mathrm{BC}$, settlement refuse comprising numerous flint artefacts and fragments of wooden artefacts such as leister prongs and arrow shafts started to cover the fire place, indicating that the site had become part of the near-shore dump zone close to a settlement on the nearby shoreline. Finally, remains of a wooden structure from the Final Mesolithic,probably a fish weir, were found, but no more settlement refuse, probably because the settlement area had shifted in response to rising sea level.

In summary, the results in this region suggest a similar pattern of settlement and cultural and economic change over the period of transition from the Late Mesolithic to the Early Neolithic as in the Wismar Bay to the west. The main difference is that faunal remains are less abundant and the effects of marine transgression and environmental change were less pronounced, with less lateral movement of the shoreline and therefore reduced possibilities for chronostratigraphic subdivision (Jöns et al. 2007, pp. 81-83; Hartz 2011, pp. 135-152).

\subsubsection{Schleswig-Holstein}

\subsubsection{Neustadt}

This site in the Bay of Lübeck was one of the first on the Baltic coast to be systematically excavated and is especially important because of the unusually large assemblages of artefacts and animal bones, the wide range of organic materials including plant remains and the evidence of continuity in fishing and plant gathering across the MesolithicNeolithic boundary. The site was discovered by a military diver in 1999 in front of the harbour at 3-4 m bpsl and excavated from 2000 to 2006, producing material belonging to the Late Ertebølle Culture (Timmendorf phase) and the Early Funnel Beaker Culture (Wangels phase) with a radiocarbon-dated sequence of 4500-3800 cal BC (Hartz and Glykou 2008; Hartz et al. 2011).

The site was originally located on the shore of a lagoon protected from the open sea by a barrier beach. An area of c. $110 \mathrm{~m}^{2}$ was excavated, of which only $10 \mathrm{~m}^{2}$ belong to the occupation area proper. The culture layer on land has been completely destroyed by marine erosion, but in front of the habitation area, and further out from the ancient shoreline, the find layer merges into peat and gyttja formed in brackish water, providing excellent conditions of preservation and large quantities of cultural debris (Fig. 5.11).

The cultural finds include some 40,000 worked flints (excluding chips), with finished tools dominated by typical Ertebølle types such as transverse arrowheads and trapezoidal flaked axes, and several thousand pot sherds, mostly from Ertebølle point-based vessels and a smaller number from blubber lamps. There were also numerous artefacts made of red deer and roe deer antler-notably T-shaped antler axes, harpoon heads, chisels and punches - and a variety of bone artefacts - awls, points, chisels, daggers and a spatula. Non-flint material comprises hammerstones and ground stone axes including two 


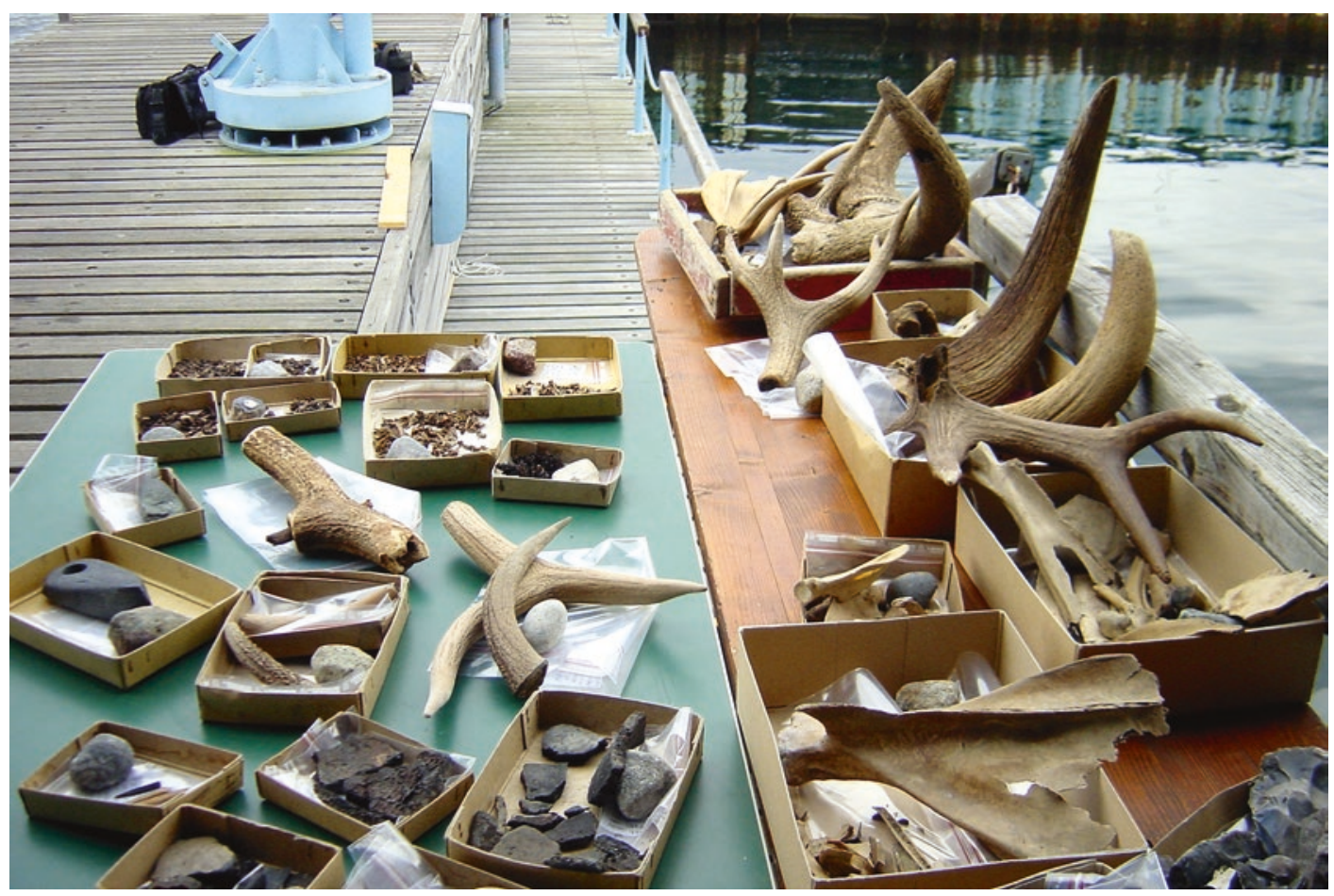

Fig. 5.11 Some of the finds from Neustadt showing the abundance and good preservation of bone and antler. Photo by Sönke Hartz, Museum for Archaeology Schloss Gottorf

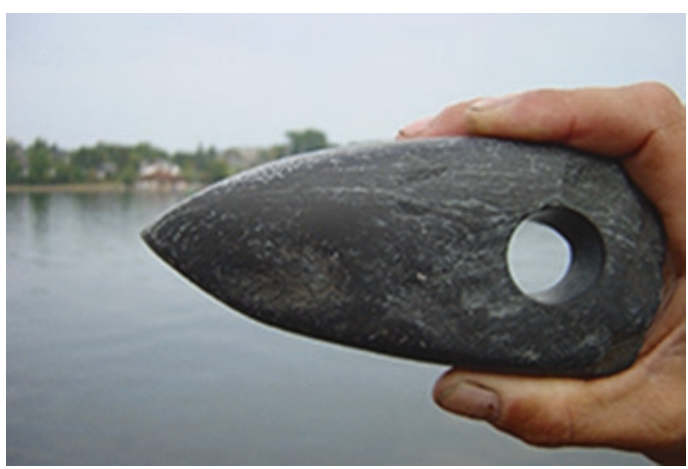

Fig. 5.12 A shaft hole axe from Neustadt made of amphibolite. The source of the amphibolite is the uplands of central Europe, and these artefacts were widely in use by the earliest Neolithic cultures of northern and central Europe, notably the Linearbandkeramik (LBK). Isolated specimens are occasionally found in Late Ertebølle sites in the western Baltic, indicating a distribution network between the farmers of central and northern Europe and their Ertebølle hunter-fisher-gatherer neighbours to the north. Photo by Sönke Hartz, Museum for Archaeology Schloss Gottorf
Danubian shaft hole axes made of amphibolite imported from the south (Fig. 5.12), underlining the special role of East Holstein in the distribution of these imports.

Wooden tools comprise a great variety of types and raw materials. There are some 26 leister prongs made of dogwood (Cornus sanguinea), hazel (Corylus avellana), ash (Fraxinus excelsior), pome fruit tree (Maloideae) and oak (Quercus sp.), four groups of fragments of logboats made of lime (Tilia sp.), 13 paddles of ash wood (Fig. 5.13), 35 fragments of spear shafts made of ash, two angled handle shafts of hazelwood for axes, four wooden handles for antler axes, the handle section of a bow made from elm wood (Ulmus sp.), remains of six arrow shafts made from ash, hazel (Fig. 5.14 left) and guelder rose (Viburnum opulus) and 60 pointed sticks and poles, mostly made from ash and representing the remains of fish weirs. Also discovered were a net float made of bark, several fragments of wicker- 


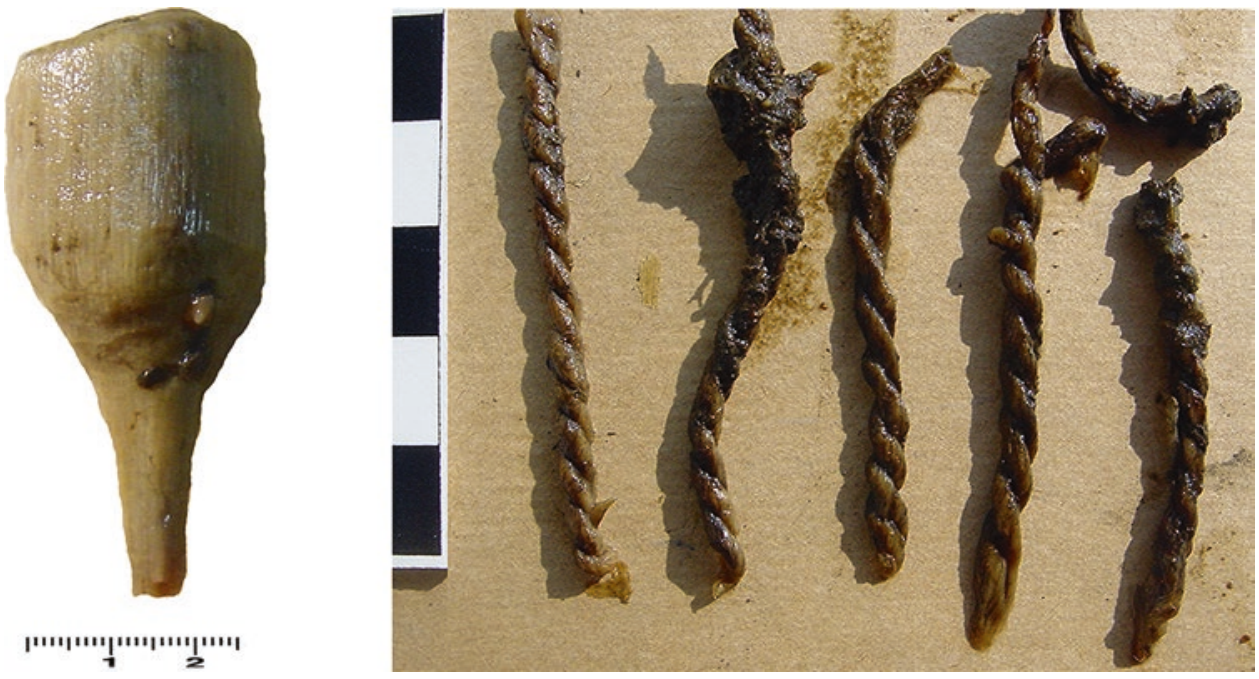

Fig. 5.13 Left: Neustadt arrowhead with club-shaped tip made from hazelwood (Corylus avellana). Right: Neustadt pieces of cord made from twisted fibres of lime bast (Tilia sp.). Photos by Sönke Hartz, Museum for Archaeology Schloss Gottorf

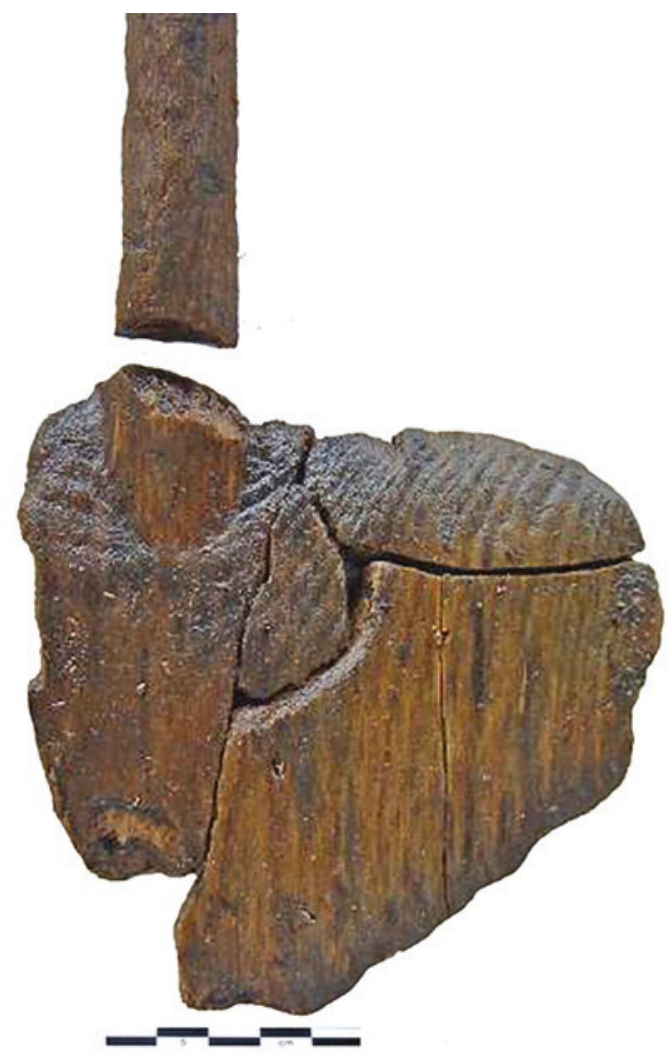

Fig. 5.14 Neustadt paddle made of ash (Fraxinus excelsior). Photo by Sönke Hartz, Museum for Archaeology Schloss Gottorf work fish traps, numerous braided and twisted cords made from tree bast (Fig. 5.14 right) and the fragments of a woven piece of textile or a net (Hartz et al. 2011, pp. 90-93).

There are many thousands of animal bones of mammals, birds and fish (Glykou 2014). Mammals and birds account for 3874 identified specimens with approximately equal representation of marine and terrestrial mammals. Water fowl (Anatidae) are dominant amongst the bird bones. Land mammals include red deer (Cervus elaphus), roe deer (Capreolus capreolus), wild boar (Sus scrofa) and aurochs (Bos primigenius). Bones of marine mammals are dominated by seals (mostly harp seal, Pagophilus groenlandicus, together with grey seal, Halichoerus grypus, and ringed seal, Pusa hispida). Bones of porpoise (Phocoena phocoena) are also quite common, and there are a few bones of dolphin (Delphinus delphis). In a fish bone assemblage of some 13,000 specimens, marine species account for $96 \%$ of identifiable bones, mostly from cod (Gadidae) but also including migratory species such as eel (Anguilla anguilla) and salmon (Salmonidae).

The Neolithic material is represented by sherds of Funnel Beaker pottery and a small 
number of bones of domestic animals (ovicaprids and cattle).

Charred food crusts are present on the interior surfaces of many of the sherds. Bulk stable isotope analysis of these residues shows that aquatic foods had been processed in both Ertebølle and Funnel Beaker vessels, whilst evidence of dairy products was present on several Funnel Beaker sherds. These data demonstrate that aquatic resources continued to play an important role in the Neolithic economy alongside agricultural products (Craig et al. 2011). Further evidence of continuity in economic practices across the Mesolithic-Neolithic transition comes from the analysis of starch granules in the food crusts, which show an emphasis on the processing of acorns in both Ertebølle and Funnel Beaker sherds (Saul et al. 2012). Preserved phytoliths in these carbonised deposits also demonstrate the use of garlic mustard (Alliaria petiolata) during the Late Mesolithic and Early Neolithic (Saul et al. 2013).

\subsubsection{Strande}

Located at a depth of $6 \mathrm{~m}$ in Kiel Bay, this site was discovered in 2011 as a result of a chance discovery by divers investigating collapsed oak-tree trunks (Fig. 5.15). Given the presence of stone artefacts and bone fragments nearby, a $5 \mathrm{~m}^{2}$ test excavation was carried out in 2012, which revealed the presence of a well-preserved cultural layer in organic sediments beneath a protective cover of marine sand (Goldhammer and Hartz 2015, 2017). This yielded many stone artefacts including waste products of tool manufacture and wooden implements, notably two leister prongs. Other organic materials, interpreted as food remains, include bones of marine and freshwater fish, mainly cod (Gadus morhua), some of which are charred, marine and terrestrial mammals including bones of red deer (Cervus elaphus) and roe deer (Capreolus capreolus) with cut marks, water birds (mostly Anatidae) and shells of acorns and hazelnuts. A tool made from the tusk of a wild boar shows use-wear probably from fur or leather

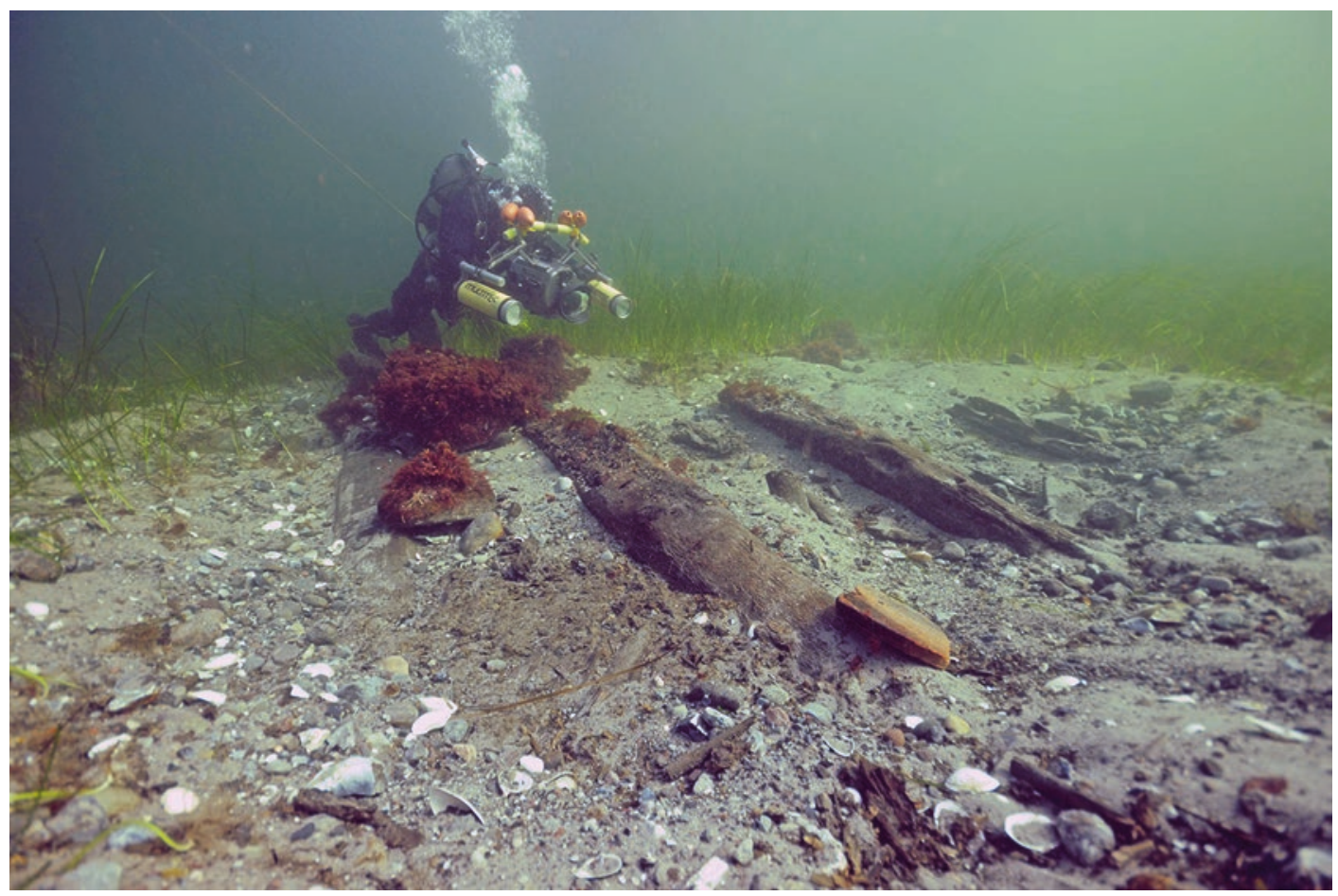

Fig. 5.15 Fallen oak trees at the Strande site in Kiel Bay, which were the first indication that an archaeological site might be preserved here. Photo by Gerald Lorenz 
processing (Glykou et al. 2014). Two pieces of human jaw bone with molar teeth and two single human teeth were also recovered. The jaw bone belongs to a female in her 20 s, while one of the single human teeth is from a second older individual (Peter Tarp and Prof Dr. JL Boldsen, Odense University, Denmark, pers. comm., 2018). Analysis of $\delta^{13} \mathrm{C}$ values indicates a diet based on marine food (Goldhammer et al. 2020).

The site is important because of its date and the extent of the deposits. The lithic assemblage is characteristic of the aceramic Ertebølle, and this is consistent with radiocarbon and tree-ring dating, which indicate a time span of 54504750 cal BC, a period which is poorly represented in other underwater sites in the region. Test pitting at regular intervals along a series of transects radiating out from the excavation area shows that sediments with preservation of organic materials and the presence of flint artefacts extend over an area of at least $2500 \mathrm{~m}^{2}$ beneath the sand layer. Further investigations are ongoing, including scientific analyses of the human remains.

\subsection{Sites in the Wadden Sea}

The main challenges to the discovery of material here are the result of the relatively rapid accumulation of marine sediments and the shallow offshore topography, as described earlier. Stone Age materials are quite deeply buried beneath thick layers of later marine sediment, and the only prospect of discovery is when storms erode some of the overlying sediment and expose the underlying land surface. This happens quite frequently and has resulted in the exposure of many prehistoric artefacts and sometimes more extensive cultural layers and features (Kühn 2007). However, once such materials have been exposed, there is the additional challenge that any systematic investigation has to be carried out in the short intervals of exposure at low tide, with all the attendant logistical problems of access and the risk that freshly dug excavation pits will be filled with sediment by the rising tide (Fig. 5.16).
At present, 42 Stone Age sites are known in the German part of the Wadden Sea (see Fig. 5.1). They are found in the mudflats associated with the North Frisian Islands of Schleswig-Holstein and the East Frisian Islands of Lower Saxony.

\subsubsection{North Frisia}

Most sites in North Frisia are of Neolithic age, demonstrating that this now-submerged landscape was part of the settlement area of the Early Neolithic Funnel Beaker Culture (Segschneider 2009). Finds include more than 20 assemblages of Neolithic flint artefacts and isolated megalith graves. Occasionally, Bronze Age finds have been recorded, as well as the remains of 'drowned' forests, which are important sources of information on the history of local settlement and topography (Kühn 2009; Kühn et al. 2013).

\subsubsection{Hamburger Hallig: A Late Neolithic Aurochs Sacrifice}

Particularly significant is the discovery of a sacrificial pit, in which the skull and bones from the extremities of a Late Neolithic aurochs had been deposited. It came to light in 2003, to the west of the island of Hamburger Hallig in North Frisia, on the edge of the deep Norderhever channel in the mudflats. When the tide was particularly low, a section of the mudflats was briefly exposed, with the tips of two partly eroded horns protruding above the surface (Fig. 5.17). An archaeological investigation revealed a pit in which the skull of a male aurochs, a vertebra and several leg bones had been buried, the latter cracked open, presumably for marrow extraction (Kühn 2009). The extremities had been placed at the bottom of the pit with the skull laid on top, suggesting a ritual deposition of specially selected parts of the carcase. Radiocarbon dating of the skull indicates deposition in the decades around $2300 \mathrm{cal} \mathrm{BC}$. The surface of the pit is now c. $3 \mathrm{~m}$ below mean high water and had been dug into a land surface that has now been partly eroded away.

Analysis of plant macrofossils from the pit fill by Helmut Kroll (University of Kiel), recorded numerous stem fragments of common reed 


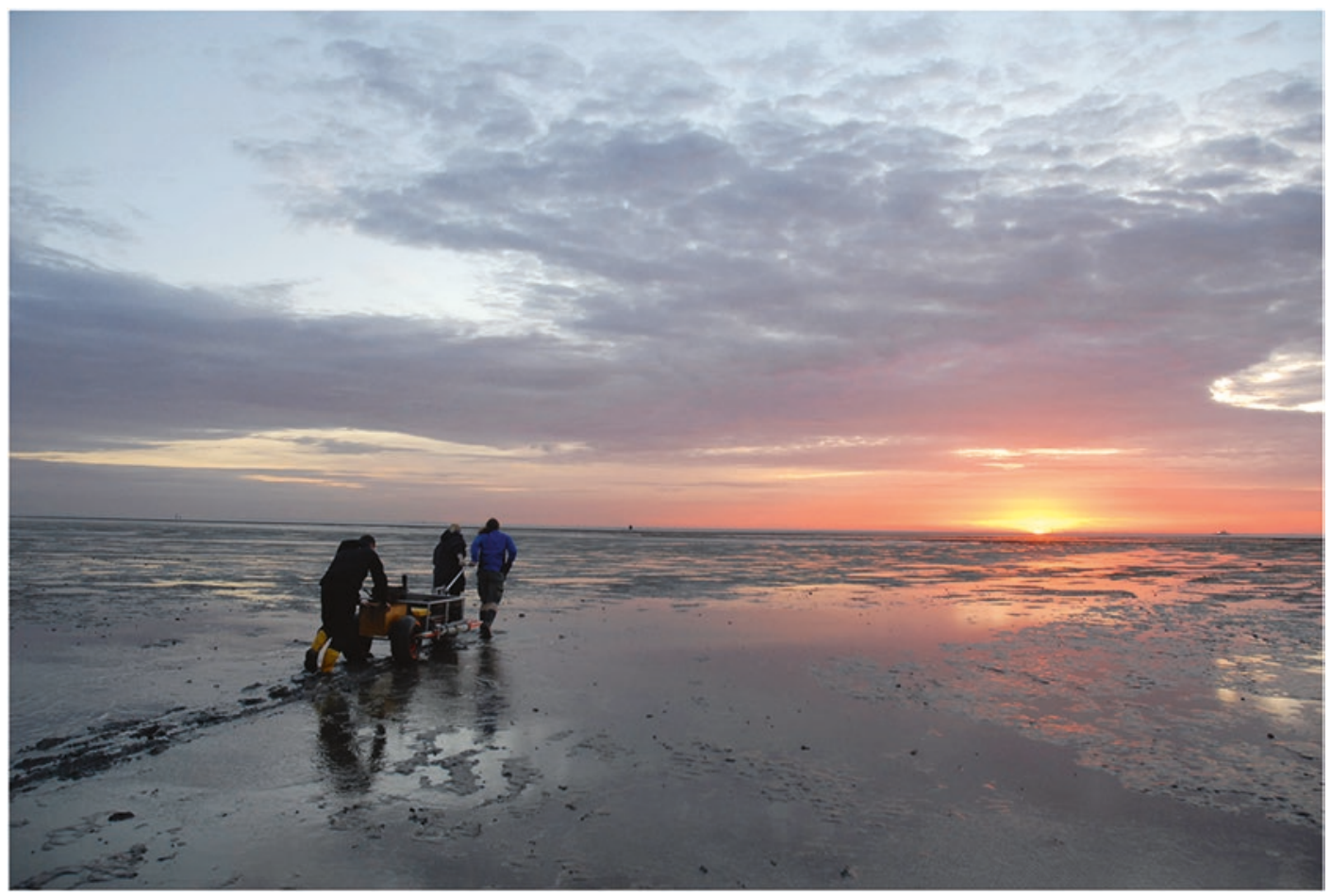

Fig. 5.16 Archaeological survey on the East Frisian mudflats of the Wadden Sea, showing the wide expanse of the intertidal zone exposed at low tide. Photo by Sunhild Kleingärtner, courtesy of Lower Saxony Institute for Historical Coastal Research

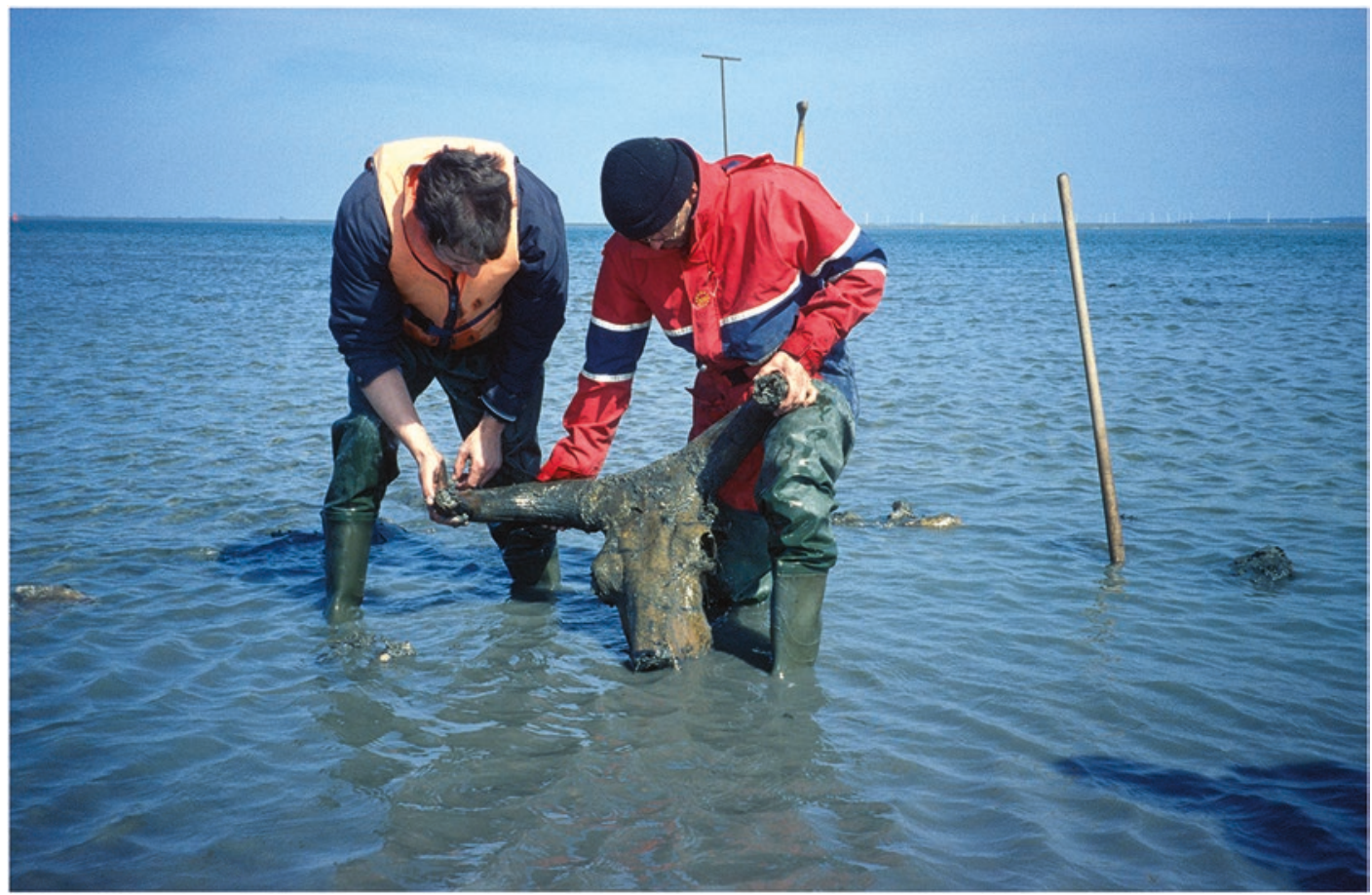

Fig. 5.17 The Late Neolithic aurochs skull at Hamburger Hallig in North Frisia during the course of its recovery. Photo by Linda Hermannsen, Archaeological State Service of Schleswig-Holstein 
(Phragmites australis) and seeds and fruits of nettle (Urtica dioica), black mustard (Brassica nigra), spear orache (Atriplex patula-type) and thistle (Cirsium arvense-type). This indicates a reed-dominated plant community which developed under freshwater conditions, demonstrating that despite rising sea level, the site had not yet been affected by marine conditions and was probably protected from the sea by a barrier of Pleistocene sediments (Kühn 2009, p. 67).

\subsubsection{East Frisia}

A total of 11 Mesolithic and Neolithic assemblages or single finds are known in this region, mostly stone tools and some antler implements. These were found along the channels between the East Frisian Islands and in river estuariesareas of strong erosion and shifting sediments, where most of the finds, especially the single finds, are not in their original location. Of particular interest is the fragment of a Late Neolithic bell beaker, which was found in the 'Ostfriesisches Gattje' region of the Ems estuary (Niederhöfer 2016, p. 100).

An additional number of finds have been identified in the files held by various authorities and museums. These include more than 20 probable Stone Age artefacts, mostly single finds. The records mention a reindeer antler, three flint axes, a flint dagger as well as numerous unidentified flint tools, an antler pick and many aurochs horns. It is no longer possible to determine the original location of any of these objects, so they cannot be placed on any find maps. Nevertheless, they, too, are evidence that the area now covered by mudflats was inhabited in prehistoric times.

\subsubsection{New Projects}

Two recent projects have been funded to expand the investigation of offshore sediments and submerged landscapes in this region. The first is Settlement and Cultural History of the Lower Saxony Wadden Sea, 2012-2015 (Jöns et al. 2013; Goldhammer and Karle 2015; Karle and Goldhammer 2017). This project analysed all existing data from geological and archaeological archives, including 30,000 sediment cores, to produce palaeogeographical maps of different time intervals and to identify areas with a high potential for archaeological remains. Most of the currently known archaeological finds are Iron Age or later in date or earlier finds that have been disturbed due to reworking of older sediments.

The second project, building on the first, is the WASA project (The Wadden Sea Archive of Landscape Evolution, Climate Change and Settlement History: Exploration - Analysis Predictive Modelling), 2016-2020. This is a multi-disciplinary and multi-institutional project combining existing archival data with new geophysical surveys, coring and sediment analysis to chart changes in sea level and landscape evolution since the Late Glacial period and to model human reactions to these changes.

\subsection{Preservation Conditions and Future Challenges}

As outlined above, the Baltic and Wadden Sea coastlines present different conditions of archaeological site preservation and visibility, and these conditions require different sorts of survey strategies. In both cases, it should be emphasised that archaeological finds become visible on the seabed surface mainly because of erosional processes.

In the Baltic, investigation has so far proved more successful for a variety of reasons. These include the greater accessibility and visibility of Stone Age palaeoshorelines, a longer history of research with a strong focus on reconstructing the pattern of sea-level rise associated with the Littorina transgression and the opportunity to elaborate research strategies suited to the conditions. The combination of different approaches in the SINCOS project has not only improved knowledge about changes in relative sea level and resulted in the discovery of a large number of Stone Age settlements but has also raised the public profile of research on underwater prehistory and landscapes and established survey routines for underwater archaeological investigation that can now be employed more widely in the 
management of the underwater cultural heritage and the conduct of investigations in advance of offshore industrial development.

Even so, most of the known submerged Stone Age sites along the German Baltic coast were originally located on the shoreline, and it is only the items of material culture that were deposited in the shallow water area in front of the sites that have been preserved. This preservation in its turn is the product of immediate submergence of the material under water and the fact that it was further sealed by a protective covering layer of marine sediment. Almost nothing is left in situ on the original dry-land surface of the settlement area, where materials have been disturbed or eroded away, except in unusual pockets of preservation such as the pit at Timmendorf-Nordmole I.

Along the Wadden Sea coastline, the shallow offshore gradients and relatively rapid accumulation of marine sediments require different methods and approaches. Most Stone Age sites in this region have been located around the North Frisian Islands, and this is because this area was drowned much later than the area of the East Frisian Islands, and its Stone Age landscapes have not been so deeply buried under marine sediments. As a general principle, the earlier the material, the more deeply buried beneath sediment it is likely to be. The currently known finds in both areas are mostly single artefacts or stray finds that have been exposed by erosional processes, and their original context is now impossible to reconstruct. In the rare case of in situ finds such as the Hamburger Hallig aurochs, these are likely to be in locations that were well inland from their contemporaneous coastline at the time of deposition, rather than in locations on or near the shoreline that could provide evidence of relative sea-level rise and exploitation of marine resources.

A systematic survey along former palaeoshorelines has not yet been carried out in the German sector of the North Sea. The major challenge in this region is the relatively thick overburden of marine sediment. If a methodology for the discovery of buried archaeological materials and a management strategy for the underwater prehistoric cultural heritage is to be developed, this will need a better knowledge of the coastal dynamics of sediment accumulation and erosion. This, in its turn, will require joint palaeoecological and archaeological investigations and the deployment of appropriately equipped research vessels over a more extensive area than has hitherto been possible. In the absence of such research investigations, industrial developments offshore in this region will be operating 'blind' without prior knowledge of areas or deposits of potential cultural significance that should be investigated in advance or avoided. Of course, offshore development may have the beneficial outcome of revealing cultural features of the buried land surface. But realising that benefit will depend on a planning process that makes adequate provision to integrate palaeoecological and archaeological investigations with planned industrial activity (see below and Pater, Chap. 27, this volume).

\subsection{Management of the Underwater Cultural Heritage}

In Germany unlike other European countries, a national legal framework for the management of the cultural heritage does not exist. Instead it is organised at the level of the Länder (the 16 states that make up the Federal Republic of Germany), with the result that there are 16 different heritage laws. For the management of the submerged sites in the Baltic waters of Germany, the responsible state heritage agencies are Mecklenburg-West Pomerania (https://www.kulturwerte-mv.de/ Landesarchaeologie) and Schleswig-Holstein (https://www.schleswig-holstein.de/DE/ Landesregierung/ALSH/alsh_node.html). The latter organisation is also in charge of research and site management of the underwater cultural heritage in the northern part of the German North Sea (North Frisia), whereas the sites in the southern part of the German North Sea (East Frisia and Lower Saxony) are the responsibility of the Ministry of Science and Culture of Lower Saxony (https://www.mwk.niedersachsen.de) advised and supported by the Lower Saxony Institute for 
Historical Coastal Research (http://www.nihk. de) and the State Agency for Cultural Heritage (http://www.denkmalpflege.niedersachsen.de/).

Underwater archaeological research in Germany is restricted to scientific divers trained by one of eight certified institutions following agreed safety education standards (http://www.forschungstauchen-deutschland.de/). Most of the recent underwater archaeological research projects along the German coast have been hosted by the Heritage Agencies of Mecklenburg-West Pomerania and Schleswig-Holstein and by the Lower Saxony Institute for Historical Coastal Research.

Because Germany has no national heritage law, underwater heritage that lies outside the area of responsibility of one of the federal states depends for protection on international laws and treaties such as the 1972 UNESCO Convention Concerning the Protection of the World's Cultural and Natural Heritage and the 1982 United Nations Convention on the Law of the Sea (see Dromgoole, Chap. 25, this volume). For offshore industrial projects such as drilling for oil and gas, sand and gravel extraction or the construction of wind farms, the 2011 EU 2011/92 directive on the assessment of the effects of certain public and private projects on the environment is of special importance. According to article 3 of this directive, Environmental Impact Assessments have to include identification, description and assessment of material assets and the cultural heritage. At the moment, it is the responsibility of the national government agency that gives planning approval to ensure that the direct and indirect effects of the planned project on cultural heritage are considered. This situation will be improved and clarified when Germany accepts and ratifies the 2001 UNESCO Convention on the Protection of the Underwater Cultural Heritage.

Acknowledgements This chapter has its origins in the SINCOS project (Sinking Coasts - Geosphere, Ecosphere and Anthroposphere of the Holocene Southern Baltic Sea). Therefore we would like to thank all the colleagues who have been part of the SINCOS team. Special thanks are due to Prof. Dr. Jan Harff, who directed this research in the friendly and consistent way that is so typical of him. In addition we would like to thank the German Research Foundation for funding the SINCOS project as well as the Strande project; without their help, it is true to say that the results of submerged landscape research in German marine waters would not have been possible. In addition, we have to thank the state authorities for the management of the archaeological heritage of Mecklenburg-West Pomerania, Schleswig-Holstein and Lower Saxony who gave us access to their heritage databases, so that we could use the data stored there as a base for our research. Finally our thanks go to two external reviewers and to Geoff Bailey for many important hints, editorial advice and extensive support during the writing of this contribution and for improvement of the English.

\section{References}

Behre K-E (2003) Eine neue Meeresspiegelkurve für die südliche Nordsee: Transgressionen und Regressionen in den letzten 10000 Jahren. Probleme der Küstenforschung im südlichen Nordseegebiet 28:9-63

Behre K-E (2007) A new Holocene sea-level curve for the Southern North Sea. Boreas 36:82-102

Behre K-E, Menke B (1969) Pollenanalytische Untersuchungen an einem Bohrkern der südlichen Doggerbank. Beiträge zur Meereskunde 24(25):122-129

Behre K-E, Dörjes J, Irion G (1984) Ein datierter Sedimentkern aus dem Holozän der südlichen Nordsee. Probleme der Küstenforschung im südlichen Nordseegebiet 15:135-148

Brinch Petersen E (1967) Klosterlund - Sønder Hadsund $\mathrm{B} \emptyset$ llund. Les trois sites principaux du Maglémosien ancien en Jutland. Essai de typologie et de chronologie. Acta Archaeologica 37:77-185

Brinch Petersen E (1973) A survey of the late Palaeolithic and the Mesolithic of Denmark. In: Kozłowski SK (ed) The Mesolithic in Europe. Papers read at the international archaeological symposium on the Mesolithic in Europe, Warsaw, May, 7-12, 1973. Warsaw University Press, Warsaw, pp 77-127

Brown A, Russel J, Scaife R, Tizzard L, Whittaker J, Wyles SF (2018) Lateglacial/early Holocene palaeoenvironments in the southern North Sea Basin: new data from the Dudgeon offshore wind farm. J Quat Sci 33(6):597-610

Cohen KM, Westley K, Erkens G, Hijma MP, Weerts HJT, Westley K (2017) The North Sea. In: Flemming NC, Harff J, Moura D, Burgess A, Bailey GN (eds) Submerged landscapes of the European continental shelf: quaternary paleoenvironments. Wiley, Chichester, pp 147-186

Coles BJ (1998) Doggerland: a speculative survey. Proc Prehist Soc 64:45-81

Craig OE, Steele VJ, Fischer A, Hartz S, Andersen SH, Donohoe P, Glykou A, Saul H, Jones DM, Koch E, Heron CP (2011) Ancient lipids reveal continuity in culinary practices across the transition to farming in Northern Europe. In: Proceedings of the National Academy of Sciences, USA 108(44):17910-17915

Enters D, Wolters S, Blume K, Lücke A, Segschneider M, Theuerkauf M (2015) Multiproxy-Analysen zur 
spät- und postglazialen Entwicklungsgeschichte des Fehmarnbelts. Siedlungs- und Küstenforschung im Nordseegebiet 38:43-58

Fries JE, Veil S (2014) Fernkontakte späteiszeitlicher Jäger und Sammler in der norddeutschen Tiefebene: Ein Klingenkern aus rotem Helgoländer Flint von einem Oberflächenfundplatz am Dümmer bei Damme, Ldkr. Diepholz. Siedlungs- und Küstenforschung im südlichen Nordseegebiet 37:125-140

Gearey BR, Hopla E-J, Smith D, Marshall P, Fitch S, Griffiths S, Tappin DR (2017) Multi-proxi paleaoecological approaches to submerged landscapes: a case study from 'Doggerland', in the Southern North Sea. In: Williams M, Hill T, Boomer I, Wilkinson IP (eds) The archaeological and forensic applications of microfossils: a deeper understandig of Human History. Geological Society, London, pp 35-53

Glykou A (2014) Late Mesolithic-early Neolithic sealers: a case study on the exploitation of marine resources during the Mesolithic-Neolithic transition in the south-western Baltic Sea In: Fernandes R, Meadows J (eds) 'Human exploitation of aquatic landscapes' special issue. Internet Archaeology 37. https://doi. org/10.11141/ia.37.7

Glykou A, Goldhammer J, Hartz S (2014) Versunkene Steinzeit - Taucharchäologische Untersuchungen an der schleswig-holsteinischen Ostseeküste. In: Huber F, Kleingärtner S (eds) Gestrandet, versenkt, versunken. Faszination Unterwasserarchäologie. Wachholtz Verlag Neumünster, Hamburg, pp 76-97

Goldhammer J, Hartz S (2015) The Ertebølle settlement Strande LA 163, District of Rendsburg-Eckernförde, and the Littorina transgression - submarine surveys and investigations. Siedlungs- und Küstenforschung an der südlichen Nordseeküste 38, pp 29-41

Goldhammer J, Hartz S (2017) Fished up from the Baltic Sea - a new Ertebølle site near Stohl cliff (Kiel Bay, Germany). In: Bailey G, Harff J, Sakellariou D (eds) Under the sea: archaeology and palaeolandscapes of the continental shelf. Springer, Cham, pp 145-154

Goldhammer J, Karle M (2015) Geoarchaeological research in the Wadden Sea area of Lower Saxony. Siedlungs- und Küstenforschung im Nordseegebiet 38:59-70

Goldhammer J, Müller AB, Brandt L, Wolters S, Hartz S (2020) Subsistence strategies, settlement structure, and communication in the terminal Mesolithic - a new DFG-project in Kiel Bay. In: Gehlen B, Zander A (eds) From the early Preboreal to the Subboreal period - current Mesolithic research in Europe. Vom frühen Präboreal bis zum Subboreal - Aktuelle Forschungen zum Mesolithikum in Europa. Kölner Studien zur Prähistorischen Archäologie, Rahden/ Westf

Grimm S, Groß D, Gerken K, Weber MJ (2020) On the onset of the early Mesolithic on the north German plain. In: Zander A, Gehlen B (eds) From the early Preboreal to the subboreal period - current Mesolithic research in Europe. Vom frühen Präboreal bis zum Subboreal - Aktuelle Forschungen zum Mesolithikum in Europa. Kölner Studien zur Prähistorischen Archäologie, Rahden/Westf

Groh A, Dietrich R, Richter A (2011) Geodetic evidence and modelling of sea-level changes and loadinduced crustal deformations in the southern Baltic Sea. Bericht der Römisch-Germanischen Kommission 92: $17-40$

Harck O (1985) Submarine Archäologie in SchleswigHolstein. Offa 42:431-446 (Feschrift Karl Kersten)

Harff J, Lüth F (2007) Preface to SINCOS I - sinking coasts: geosphere, ecosphere and anthroposphere of the Holocene southern Baltic Sea. Bericht der Römisch-Germanischen Kommission 88:9-14

Harff J, Lüth F (2011) Preface to SINCOS II - sinking coasts: geosphere, ecosphere and anthroposphere of the Holocene southern Baltic Sea. Bericht der Römisch-Germanischen Kommission 92:11-16

Harff J, Meyer M (2007) Changing Holocene coastal zones of the Baltic Sea - a modelling approach. Bericht der Römisch-Germanischen Kommission 88:241-266

Harff J, Lemke W, Lampe R, Lüth F, Lübke H, Meyer M, Tauber F, Schmölcke U (2007) The Baltic Sea coasta model for interrelations among geosphere, climate, and anthroposphere, Special paper 426. Geological Society of America, New York, pp 133-142

Harff J, Flemming NC, Groh A, Hünicke B, Lericolais G, Mesched M, Rosentau A, Sakellariou D, Uścinowicz S, Zhang W, Zorita E (2017) Sea level and climate. In: Flemming NC, Harff J, Moura D, Burgess A, Bailey GN (eds) Submerged landscapes of the European continental shelf: quaternary paleoenvironments. Wiley, Chichester, pp 21-49

Hartz S, Glykou A (2008) Neues aus Neustadt. Ausgrabungen zur Ertebølle- und frühen Trichterbecher-Kultur in Schleswig-Holstein Archäologische Nachrichten aus Schleswig-Holstein 14:17-19

Hartz S, Lübke H (2006) New evidence for a chronostratigraphic division of the Ertebølle culture and the earliest Funnel Beaker culture on the Southern Mecklenburg Bay. In: Kind CJ (ed) After the Ice age: settlements, subsistence and social development in the Mesolithic of Central Europe: proceedings of the international conference 9th to 12th of September 2003, Rottenburg/Neckar, Baden-Württemberg, Germany. Materialhefte zur Archäologie in Baden-Württemberg 78:61-77

Hartz S, Jöns H, Lübke H, Schmölcke U, von CarnapBornheim C, Heinrich D, Klooß S, Lüth F, Wolters S (2011) Prehistoric settlements in the southwestern Baltic Sea area and development of the regional stone age economy. Bericht der Römisch-Germanischen Kommission 92:77-210

Hepp DA, Warnke U, Hebbeln D, Mörz T (2017) Tributaries of the Elbe palaeovalley: features of a hidden palaeolandscape in the German Bight, North Sea. In: Bailey GN, Harff J, Sakellariou D (eds) Under the sea: archaeology and palaeolandscapes of the continental shelf. Springer, Cham, pp 211-222 
Holst D (2014) Subsistenz und Landschaftsnutzung im Frühmesolithikum. Nussröstplätze am Duvensee. Monographien des Römisch-Germanischen Zentralmuseums 120, Römisch-Germanisches Zentralmuseum, Regensburg

Jöns H (2010) The Wadden Sea as a cultural landscape and an archive of common history. In: Marencic H., Eskildsen K., Farke H, Hedtkamp S (eds) Science for nature conservation and management: the Wadden Sea ecosystem and EU directives. Proceedings of the 12th International scientific wadden Sea symposium in Wilhelmshaven, Germany, 30 March-3 April 2009. Wadden Sea Ecosystem No. 26. Common Wadden Sea Secretariat, Wilhelmshaven, Germany, pp 163-164

Jöns H (2011) Settlement development in the shadow of coastal changes. Case studies from the Baltic rim. In: Harff J, Björck S, Hoth P (eds) The Baltic Sea basin. Springer, Berlin/Heidelberg, pp 301-336

Jöns H, Lübke H, Lüth F, Terberger T (2007) Prehistoric settlements and development of the regional economic area. Archaeological investigations along the Northeast-German Baltic Seacoast. Bericht der Römisch-Germanischen Kommission 88:149-188

Jöns H, Karle M, Kleingärtner S (2013) Das Nordseebecken und der Wattenmeerraum als Forschungsgebiet. Methodische Überlegungen, Strategien und aktuelle Forschungsprojekte. Offa 69/70:71-80

Karle M, Goldhammer J (2017) The Wadden Sea of North-West Germany: an intertidal environment of high archaeological research potential. In: Bailey GN, Harff J, Sakellariou D (eds) Unter the sea: archaeology and palaeolandscapes of the continental shelf. Springer, Cham, pp 223-231

Klooß S (2015) Mit Einbaum und Paddel zum Fischfang. Holzartefakte von endmesolithischen und frühneolithischen Küstensiedlungen an der südwestlichen Ostseeküste, Untersuchungen und Materialien zur Steinzeit in Schleswig-Holstein und im Ostseeraum 6. Wachhotz/Murmann Publishers, Kiel/Hamburg

Krüger S, Dörfler W, Bennike O, Wolters S (2017) Life in Doggerland - palynological investigations of the environment of prehistoric hunter-gatherer societies in the North Sea Basin. E\&G Quaternary Sci J 66:3-13

Kühn HJ (2007) Jenseits der Deiche. Archäologie im nordfriesischen Wattenmeer. In: Von CarnapBornheim C, Radtke C (eds) Es war einmal ein Schiff. Archäologische Expeditionen zum Meer. Mareverlag, Hamburg, pp 251-285

Kühn HJ (2009) Flintdolche im Schlick. Archäologische Nachrichten aus Schleswig-Holstein 2009:66-70

Kühn HJ, Meier D, Mertens C (2013) Dokumentation der Kulturspuren. In: Meier D, Kühn HJ, Borger GJ (eds) Der Küstenatlas. Das schleswig-hoslteinische Wattenmeer in Vergangenheit und Gegenwart. Boyens Buchverlag, Heide, pp 49-56

Lampe R, Meyer H, Ziekur R, Janke W, Endtmann E (2007) Holocene evolution of the irregularly sinking southern
Baltic Sea coast and the interactions of sea-level rise, accumulation space and sediment supply. Bericht der Römisch-Germanischen Kommission 88:15-46

Lanting JN, Van der Plicht JH (2000) De ${ }^{14}$ C-chronologie van de Nederlandse pre- en protohistorie: II. Mesolithicum. Palaeohistoria 39(40):99-162

Lübke H (2001) Eine hohlendretuschierte Klinge mit erhaltener Schäftung vom endmesolithischen Fundplatz Timmendorf-Nordmole, Wismarbucht, Mecklenburg-Vorpommern. Nachrichtenblatt des Arbeitskreises für Unterwasserarchäologie 8:46-51

Lübke H (2002) Steinzeit in der Wismarbucht. Ein Überblick Nachrichtenblatt des Arbeitskreises für Unterwasserarchäologie 9:75-88

Lübke H (2003) New investigations on submarine Stone Age settlements in the Wismar Bay area. In: Kindgren H, Knutsson K, Larsson L, Loefler D, Akerlund A (eds) Mesolithic on the move: papers presented at the sixth international conference on the Mesolithic in Europe, Stockholm 2000. Oxbow, Oxford, pp 633-642

Lübke H, Schmölcke U, Tauber F (2011) Mesolithic hunter-fishers in a changing world: a case study of submerged sites on the Jäckelberg, Wismar Bay, northeastern Germany. In: Benjamin J, Bonsall C, Pickard C, Fischer A (eds) Submerged prehistory. Oxbow, Oxford, pp 21-37

Mahlstedt S (2015) Das Mesolithikum im westlichen Niedersachsen. Untersuchungen zur materiellen Kultur und zur Landschaftsnutzung, Frühe Monumentalität und soziale Differenzierung 7. Habelt, Bonn

Müller J, Brozio J-P, Demnick D, Dibbern H, Fritsch B, Furholt M, Hage F, Hinz M, Lorenz L, Mischka D, Rinne C (2010) Perdiodisierung der TrichterbecherGesellschaften. Ein Arbeitsentwurf. J Neolithic Archaeol 12. Available at: https://doi.org/10.12766/ jna. 2010.58

Niederhöfer K (2016) Archäologische Fundstellen im ostfriesischen Wattenmeer. Siedlungsgeschichte einer untergegangenen Landschaft bis 1570. Beiträge zur Archäologie in Niedersachsen 18. Archäologische Kommission für Niedersachsen, Rahden

Niekus M (2006) A geographically referenced ${ }^{14} \mathrm{C}$ database for the Mesolithic and the early phase of the Swifterbant culture in the northern Netherlands. Palaeohistoria 47(48):41-99

Policy Research Corporation (2009) The economics of climate change adaptation in EU coastal areas. Country reports: Germany. Available at: https:// ec.europa.eu/maritimeaffairs/documentation/studies/ climate_change_en. Accessed 18 Dec 2018

Raemaekers DCM (1999) The articulation of a "New Neolithic": the meaning of the Swifterbant culture for the process of neolithisation in the western part of the North European Plain (4900-3400 BC). Leiden University Press, Leiden

Rosentau A, Bennike O, Uścinowicz S, MiotkSzpiganowcz G (2017) The Baltic Sea Basin. In: Flemming NC, Harff J, Moura D, Burgess A, Bailey 
GN (eds) Submerged landscapes of the European continental shelf: quaternary paleoenvironments. Wiley, Chichester, pp 103-133

Saul H, Wilson J, Heron CP, Glykou A, Hartz S, Craig OE (2012) A systematic approach to the recovery of and identification of starches from carbonized deposits on ceramic vessels. J Archaeol Sci 39:3483-3492

Saul H, Madella M, Fischer A, Glykou A, Hartz S, Craig OE (2013) Phytoliths in pottery reveal the use of spice in European prehistoric cuisine. PLoS One 8(8): 70583

Schlichtherle H (ed) (1997) Pfahlbauten rund um die Alpen. Archäologie in Deutschland Sonderheft, Stuttgart

Schmölcke U, Glykou A, Heinrich D (2007) Faunal development in the southwestern Baltic area. Bericht der Römisch-Germanischen Kommission 88:205-218

Segschneider M (2009) Die Nordsee - eine jahrtausendealte Kulturlandschaft; wo gestern noch Lärm und lustiger Tisch. Archäologie in Deutschland 6:28-31

Shennan I, Lambeck K, Flather R, Horton B, McArthur J, Innes J, Lloyd J, Rutherford M, Wingfield R (2000) Modelling Western North Sea palaeogeographies and tidal changes during the Holocene. In: Shennan I, Andrews J (eds) Holocene land-ocean interaction and environmental change around the North Sea, London, pp 299-319

Skaarup J (1995) Excavation of a Mesolithic dwelling in a submerged landscape. Preliminary report. News in WARP: the newsletter of the Wetland Archaeology Research Project 17:28-31

Sørensen SA (2016) Syltholm: Denmark’s largest Stone age excavation. Mesolithic Miscellany 24(2):1-10
Sørensen SA (2017) The Kongemose culture. Nordiske Fortidsminder, Serie B, Bind 27. Copenhagen

Stapel B (1991) Die geschlagenen Steingeräte der Siedlung Hüde I am Dümmer. Veröffentlichungen der Urgeschichtlichen Sammlungen des Landesmuseums zu Hannover 38. Hildesheim

Streif HJ (2004) Sedimentary record of Pleistocene and Holocene marine inundations along the North Sea coast of Lower Saxony, Germany. Quat Int 112:3-28

Ten Anscher TJ (2015) Under the radar: Swifterbant and the origins of the funnel beaker culture. In: Kabaciński J, Hartz S, Raemaekers D (eds) The Dąbki site in Pomerania and the Neolithisation of the North European Lowlands (c. 5000-3000 cal BC). Verlag Marie Leidorf, Rahden, pp 335-358

Terbeerger T (2007) Neue Forschungen am steinzeitlichen Fundplatz Ralswiek-Augustenhof, Kr. Rügen. In: Speitel E (ed) Terra Prehistorica. Festschrift für KlausDieter Jäger zum 70. Geburtstag, Beiträge zur Ur- und Frühgeschichte Mitteleuropas, vol 48. Beier \& Beran, Langenweißbach, pp 241-252

Wolters S (2009) Neue Daten zur Vegetationsgeschichte der südlichen Nordsee. Pollenanalytische Untersuchungen an in-situ Torflagern und Torfgeröllen. Nachrichten des Marschenrates zur Förderung der Forschung im Küstengebiet der Nordsee 45:53-57

Wolters S, Zeiler M, Bungenstock F (2010) Early Holocene environmental history of sunken landscapes: pollen, plant macrofossil and geochemical analyses from the Borkum Riffgrund, southern North Sea. Int J Earth Sci 99:1707-1719

Open Access This chapter is licensed under the terms of the Creative Commons Attribution 4.0 International License (http://creativecommons.org/licenses/by/4.0/), which permits use, sharing, adaptation, distribution and reproduction in any medium or format, as long as you give appropriate credit to the original author(s) and the source, provide a link to the Creative Commons licence and indicate if changes were made.

The images or other third party material in this chapter are included in the chapter's Creative Commons licence, unless indicated otherwise in a credit line to the material. If material is not included in the chapter's Creative Commons licence and your intended use is not permitted by statutory regulation or exceeds the permitted use, you will need to obtain permission directly from the copyright holder.

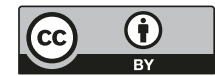

